Article

\title{
Power Substation Construction and Ventilation System Co-Designed Using Particle Swarm Optimization
}

\author{
Jau-Woei Perng ${ }^{1}$, Yi-Chang Kuo ${ }^{1,2, * \mathbb{C}}$, Yao-Tsung Chang ${ }^{2}$ and Hsi-Hsiang Chang ${ }^{2}$ \\ 1 Department of Mechanical and Electro-Mechanical Engineering, National Sun Yat-sen University, \\ Kaohsiung 80424, Taiwan; jwperng@faculty.nsysu.edu.tw \\ 2 Taiwan Power Company Southern Region Construction Office, Kaohsiung 81166, Taiwan; \\ u744793@taipower.com.tw (Y.-T.C.); u785016@taipower.com.tw (H.-H.C.) \\ * Correspondence: a0917689485@gmail.com; Tel.: +886-3676901
}

Received: 19 February 2020; Accepted: 21 April 2020; Published: 6 May 2020

\begin{abstract}
This study discusses a numerical study that was developed to optimize the ventilation system in a power substation prior to its installation. We established a multiobjective particle swarm optimizer to identify the best approach for simultaneously improving, first, the ventilation performance considering the most appropriate inlet size and outlet openings and second, the reduction of the synthetic noise of the ventilation and power consumption from the exhaust fan equipment and its operation. The study used building information modeling to construct indoor and outdoor models of the substation building and verified the overall performance using ANSYS FLUENT 18.0 software to simulate the air velocity and air temperature distribution within the building. Results show that the exhaust fan of the B1F cable finishing room and the $23 \mathrm{kV}$ gas insulated switchgear (GIS) room optimize the reduction of horsepower by approximately $1 \mathrm{Hp}$ and $0.5 \mathrm{Hp}$. The combined noise is reduced by $4 \mathrm{dBA}$ and $2 \mathrm{dBA}$; the exhaust fan runs for $30 \mathrm{~min}$, and the two equipment rooms can cool down by $2.9^{\circ} \mathrm{C}$ and $1.7^{\circ} \mathrm{C}$, respectively. Therefore, it is confirmed that the MOPSO algorithm provides a more energy-efficient and environmentally friendly building ventilation environment.
\end{abstract}

Keywords: power substation; inlet and outlet openings; synthetic noise; multiobjective particle swarm optimizer; exhaust fan; gas insulated switchgear

\section{Introduction}

Previously, because of proper architectural design and natural environment, natural ventilation could be used to develop a healthy and comfortable living space. Nowadays, because of the excessive consumption of natural resources, energy crisis, considerable reduction in natural resources, and environmental degradation, we need to consider not only the impact and destruction of life because of damage to the ecological environment but also the importance and necessity of sustainable development. Previously, the ventilation of most residential buildings was dependent on the openings of the building for natural ventilation; however, when the natural ventilation conditions were insufficient to affect the comfort of indoor space, an air conditioner was used to decrease the discomfort for building users. Because of the awareness of environmental protection, we advocate using natural methods and replace the use of mechanical energy. Studies on natural ventilation and practical application methods have been conducted for several years; however, these methods are often difficult to operate because of differences in climatic conditions and microclimate environments in various regions [1-6]. The "hybrid ventilation system" is based on the natural ventilation and is supplemented by mechanical ventilation; moreover, it pursues the consumption of the least number of 
resources to achieve the best indoor environmental quality for sustainability, low energy consumption, and preservation of humanity. In addition to improving the quality of the environment, it also considers both health and sustainability. Several researchers have published various algorithms to optimize the ventilation efficiency and reduce engineering costs. For example, Petri et al. [7] introduced the energy optimization of existing buildings using the building information modeling (BIM) software to obtain the building and electricity consumption data related to the equipment used in the buildings' heating, ventilation, and air conditioning (HVAC) system in the building for a long term. They used a multiobjective genetic optimization algorithm (NSGAII) to optimize the electricity consumption of the HVAC equipment. Furthermore, based on the results, it was confirmed that the building energy model showed that the established NSGAII algorithm could be used to build the HVAC system and thus achieve a cost-effective economic benefit. Moreover, Ma et al. [8] proposed a dual gradient search method for energy management based on temperature optimization, energy supply, and price for constructed buildings (HVAC). Furthermore, Sporr et al. [9] used information from BIM to design control strategies such as integrity checks and enhancements to the dataset from the necessary information, as well as clarified how operational data from the energy system could be used to modify the existing buildings and HVAC controller. Ke et al. [10] presented a cooling design for a tunnel's machine room at the Zhonghe Xinlu Line Xinzhuang Huilong Section of the Taipei MRT, i.e., the side was installed with a vertical ventilation shaft. The results showed that the cross-sectional area of the vertical ventilation shaft affected both ventilation volume and temperature of the tunnel machine room. Moreover, the computational fluid dynamics (CFD) software was used to simulate the ventilation environment of the subway tunnel's machine room to achieve the cooling system design's benefits. Furthermore, on both sides of each station in the Xinzhuang Huilong section, tunnel ventilation and vertical wells were installed. This study is unique because the design of ventilation and electromechanical equipment in the substation was optimized before the construction. Ke et al. [10] also indicated that the ventilation opening area is inversely related to the indoor temperature and air-exchange volume but that the ventilation opening area can be increased to enhance the cooling effect. However, the ventilation opening area cannot be infinitely increased to affect the civil structure. In future, the aim of the multiobjective particle swarm optimizer (MOPSO) optimization design for the substation ventilation system will be to determine a balance between the civil structure and electromechanical equipment design such that it reduces the cost of electricity and maintains the ventilation system subsequent to completing the construction. In consideration of the varying land sizes, climates, temperatures, and humidity in different countries, the voltage of transformer substations is also different to avoid energy attenuation owing to the distance of power transmission from the power plant to the transformer substation; consequently, the voltage grade, cable, and transformer size of the transformer substation are also different. Therefore, the equipment may have different spaces and heating values. As Taiwan's voltage grade of a transformer substation is different from that of global transformer substations, we are unable to compare the improvement effects of the ventilation system in the same space, but we must compare the improvement methods for ventilation system in the equipment room with global transformer substations. According to the improvement of ventilation systems in transformer substations [11-15] reported by studies from other countries in recent years, H. Liu et al. (2017) proposed a study on the application of COMSOL software in ventilation design and application of transformer substations; they concluded that power consumption and synthetic noise will be increased in the transformer substation if ventilation equipment is increased [11]. In 2018, M. Kanaan et al. and FAS Bahri et al. reduced the temperature of the equipment room by changing the position of the inlet/outlet $[12,13]$ and simulated indoor cooling effects via fluid mechanics, but they did not analyze the windward side of the building, power consumption of power equipment, and synthetic noise. In 2019, Yun Liu et al. investigated the mean lowest temperature in the equipment room using the variational method and adjusted the ventilation equipment; however, the sole objective of this study was to optimize the indoor temperature of equipment to the lowest mean performance value and re-plan the ventilation equipment, but no multiple-target optimization plan was prepared for 
the power consumption and synthetic noise of ventilation equipment [14]. F Liu et al. studied the synthetic noise of the equipment room [15]. However, all the above studies had no plans or designs on reducing the temperature of the equipment room by optimizing inlet/outlet size via machine learning, energy conservation design, or noise reduction of continuous cooling equipment. Besides, there are many reports on application of machine learning in power systems [16-20], but they have not yet been applied in the ventilation system of a transformer substation. The remainder of this paper is organized as follows. In Section 1, we review the ventilation and cooling effects of the ventilation system equipment used to prevent an increase in the temperature in the equipment room of the substation and the generation of undesirable gases. In Section 2, we describe the materials and methods used in the system structure. In Section 3, we report and analyze the simulation results. Finally, in Section 4, we provide the conclusions and discussions of this study.

\subsection{Establishing a Ventilation System to Prevent Increase in the Temperature in the Equipment Room} of the Substation and Generation of Adverse Gases

The substation buildings need to be provided with a number of inlet/outlet openings for ventilation on both the inner and outer walls. Because ventilation facilities, such as ducts, need considerable space, the ventilation design should consider the space required for the installation, maintenance, and operation of the internal compartment configuration, ventilation facilities, and substation equipment. The design of the ventilation equipment is closely related to the appearance of the building, the firefighting equipment, the installation of the substation equipment, and the function of the substation. Therefore, the planning and design of the ventilation system should be carried out along with those of the building to minimize the revisions of the plan view and elevation view of the building as well as facilitate the acquisition of construction permits. For the firefighting function, both the air inlet and outlet ports in each fire and $\mathrm{CO}_{2}$ protection zone compartment (including its buffer zone) shall be provided with an electric damper that can be automatically closed and shut off before the $\mathrm{CO}_{2}$ fire-extinguishing agent is irradiated to ensure appropriate $\mathrm{CO}_{2}$ concentration is obtained, which can be calculated using formulas (1)-(3) [21]. Furthermore, the fan, damper, and other facilities can be manually turned on the total monitoring panel to discharge harmful gases such as $\mathrm{CO}_{2}$ to the outside.

$$
\begin{aligned}
& \mathrm{CO}_{2} \text { concentration }=\frac{G}{G+V} \times 100 \%, \\
& \mathrm{O}_{2} \text { concentration }=\frac{0.21 \times V}{G+V} \times 100 \%,
\end{aligned}
$$

V: Chamber volume $\left(\mathrm{m}^{3}\right)$; $\mathrm{G}$ : $\left(\mathrm{CO}_{2}\right.$ release, $\left.\mathrm{m}^{3}\right)=\mathrm{CO}_{2}$ weight $(\mathrm{kg}) \times$ volume factor $\left(0.534 \mathrm{~m}^{3} / \mathrm{kg}\right)$.

In addition, fans, dampers, and other facilities can manually turn on the total monitoring panel to discharge harmful gases, such as $\mathrm{CO}_{2}$, to the outside.

The concentration of $\mathrm{CO}_{2}$ should not be less than $34 \%$ and that of $\mathrm{O}_{2}$ should not be greater than $13.86 \%$.

Based on relevant building regulations, [22,23] the distribution room, transformer room, and reactor room need to be equipped with a fire-venting damper that fulfills the requirement of firefighting timeliness for $2 \mathrm{~h}$ or more; however, the remaining $\mathrm{CO}_{2}$ protection zone must be equipped with a fire-venting damper that fulfills the requirement of firefighting timeliness for $1 \mathrm{~h}$ or more.

The ventilation of an indoor substation should be designed as natural air inlet/mechanical outlet ventilation [24-32]. When each room is independently ventilated, the required fan is generally placed outside the ventilation room or in space that does not affect the operation and maintenance of the equipment in the same room to directly discharge hot air, outlet gas, etc. If necessary, the fan can be located elsewhere and a separate duct or air duct can be set to guide the inlet/outlet. The ventilation fan should have a safe maintenance working space without the need for a shutdown of the substation equipment. The used cable processing room, transformer room, reactor room, GIS room, and system capacity (SC) room at all levels should be equipped with two and more units of fans according to the 
total air volume. The ventilation of the underground substation or semi-underground substation can be designed using the natural air inlet/mechanical outlet or mechanical air inlet/mechanical outlet, and a centralized air inlet duct and outlet duct shall be provided. The fans used in each room on each floor are installed in the fan room in a centralized manner, and facilities such as air ducts, air channels, and dampers are installed to guide the ventilation of each room. The inlet/outlet of each ventilation zone should be independent and unaffected by other ventilation zones. The indoor reference temperature (ti) is maintained at $40^{\circ} \mathrm{C} \mathrm{DB}$ (dry bulb temperature), while the outdoor reference temperature (to) is $36^{\circ} \mathrm{C}$ DB.

The ventilation volume is calculated by considering the calorific value of the device and the air-exchange times and considering the relative maximum air volume value. Furthermore, the ventilation volume is calculated from the air-exchange times in the place specified in Table 1 [33], and the ventilation volume of respective rooms in Tables 2 and 3 are calculated using the calorific value of the device. The calculation formula of each ventilation volume has been described below.

\subsubsection{Air Change Rate Conversion Method}

The calorific values of certain devices may not be considerable; however, they can produce harmful substances such as odor, moisture, and corrosive gas. Moreover, there must still be sufficient ventilation volume to be discharged to the outside to maintain the indoor air quality.

$$
\mathrm{Qc}=\frac{\mathrm{V} \times \mathrm{N}}{60}
$$

$\mathrm{Q}_{\mathrm{c}}$ : Ventilation volume $\left(\mathrm{m}^{3} / \mathrm{min} ; \mathrm{CMM}\right)$

$\mathrm{N}$ : Air change rate (times/h). See Table 1.

$\mathrm{V}$ : Indoor volume $\left(\mathrm{m}^{3}\right)$

\subsubsection{Calorific Value Conversion Method}

The conversion formula (5) for obtaining the ventilation volume through the calorific value of the device is as follows:

$$
\mathrm{Qh}=\frac{\mathrm{H} \times 860}{(60 \times 0.29 \times \Delta \mathrm{t})}
$$

$\mathrm{Q}_{\mathrm{h}}$ : Ventilation volume (CMM)

$\mathrm{H}$ : Thermal power emitted by the device $(\mathrm{kW})$. See Tables 2 and 3.

$\Delta t$ : Indoor and outdoor temperature difference, i.e., $\Delta t=t_{i}-t_{0}$.

\subsubsection{Calculation of Ventilation Openings}

To reduce water intrusion, the ventilating inlet/outlet opening should be waterproof and splash-proof, and an appropriate silencing louver or the sound-reducing enclosure should be provided according to the noise calculation. If the building design can meet the requirements of waterproofing and noise reduction, these setups will be exempted. The opening size for mounting the louver, the silencing louver, or the sound-reducing enclosure can be calculated as follows:

$$
\mathrm{V}=\frac{\mathrm{Q}}{60 \mathrm{~A} \times \text { Percentage of Opening in the Louver }}
$$

A: Wall opening area $\left(\mathrm{m}^{2}\right)$

Q: Ventilation volume $(\mathrm{CMM})$

$\mathrm{V}$ : Louver conversion wind speed $(\mathrm{m} / \mathrm{s})$.

The speeds of the air inlet, outlet, and the roof exhaust fans should be $<4 \mathrm{~m} / \mathrm{s},<6 \mathrm{~m} / \mathrm{s},<10 \mathrm{~m} / \mathrm{s}$, respectively. The level of air pressure is related to the density of air. When the air is compressed 
in a narrow space, the density increases, the weight of the air increases, the pressure per unit area rises, and a high air pressure is formed and vice versa. The relation between wind and air pressure: Air and water can flow similarly. Affected by gravity, the heavier will sink and the lighter will float. If the high and low air pressures are in an up and down relation, the air will move up and down; however, if the high and low air pressures are in the left and right relation, the air will move in parallel. Note that this air flow is the wind; therefore, the greater the difference in air pressure, the greater is the wind speed. The centrifugal fan uses the shaft power to rapidly rotate the fan blade, thus compressing the air to the outer edge of the fan blade and forming a positive air pressure difference:

$$
\mathrm{P}=\frac{\mathrm{V}^{2} \mathrm{r}}{2 \mathrm{~g}}
$$

$\mathrm{V}$ : Louver conversion wind speed $(\mathrm{m} / \mathrm{s})$

P: Static pressure of the opening (mmAq)

$\mathrm{r}$ : Air specific gravity $=1.2 \mathrm{~kg} / \mathrm{m}^{3}$

g: Gravity acceleration $=9.8 \mathrm{~m} / \mathrm{s}^{2}$

Table 1. Rate of air changes in each room/space.

\begin{tabular}{cc}
\hline Name of the Room/Space & $\begin{array}{c}\text { Air Change Rate in Each Room/Space } \\
\text { (Number of Changes/h) }\end{array}$ \\
\hline $\begin{array}{c}\text { DC power supply room, pressure-regulating chamber, } \\
\text { elevator machinery room }{ }^{\text {Note } 1, \text { UPS room, toilet }} \\
\begin{array}{c}\text { Pantry, workroom, emergency generator room Note 2 } \\
\text { Fire equipment room, underground walkway, tools room, } \\
\text { pipe space, warehouse }\end{array}\end{array}$ & 16 and more \\
\hline
\end{tabular}

Note 1: If the specified air changes rates can be achieved, the natural ventilation design can also be used. Note 2: The air change rates of the elevator machinery room and emergency generator room are for indoor ventilation only, and the ventilation volume required to eliminate the heat from operations of the elevator and emergency generator (see Table 2). Proper inlet/outlet ventilation openings and related facilities should be set up.

For places not listed in Tables 1 and 2, if mechanical ventilation is required the ventilation volume should be calculated based on six times of ventilation per hour (unless otherwise specified). The surrounding conditions of the air inlet or outlet port should be considered, and the appropriate mounting surface and height and set positions should be selected such that the ventilation short circuit will not occur and the indoor air distribution will be uniform without local retention. The opening height of the air inlet or outlet port should meet the following requirements: the top of the opening of the outlet port should be $10 \mathrm{~cm}$ below the beam, while the bottom of the opening of the air inlet should be $50 \mathrm{~cm}$ above the floor. When the air inlet is located on the wall adjacent to the road outside the substation, the height of the bottom of the opening should be $>2 \mathrm{~m}$ above the ground. When the outlet port is located in a park or a square, the bottom height of the opening should be $>3 \mathrm{~m}$ above the ground to prevent the hot air from being directly blown to the pedestrian. It should be installed at the bottom of the opening of the air inlet and outlet ports on the outer wall of the first floor and placed at $>100 \mathrm{~cm}$ above the floor. Moreover, anti-theft measures should be adopted, and the top of the remaining outlet openings should be $10 \mathrm{~cm}$ below the beam, whereas the bottom of the air inlet opening should be $50 \mathrm{~cm}$ above the floor. 
Table 2. Calorific values for electromechanical equipment in a substation.

\begin{tabular}{|c|c|c|c|}
\hline $\begin{array}{l}\text { Name of the } \\
\text { Room/Space }\end{array}$ & Equipment Capacity & Calorific Value (kw) & Remarks \\
\hline \multirow{7}{*}{ Transformer room } & 345 kV 500 MVA A.TR & 135/set & \multirow{7}{*}{ Note 3} \\
\hline & $345 \mathrm{kV} 167$ MVA A.TR & $38 /$ set & \\
\hline & 161 kV 200 MVA M.TR & $62 /$ set & \\
\hline & 161 kV 60 MVA D.TR & 20/set(OIT), 30/set(GIT) & \\
\hline & $161 \mathrm{kV} 30 \times 2$ MVA D.TR & 30/set(OIT), 50/set(GIT) & \\
\hline & 161 kV 30 MVA D.TR & $14 /$ set & \\
\hline & 69 kV 25 MVA M.TR & 9/set & \\
\hline \multirow{4}{*}{ Reactor room } & 33 kV 40MVAR SH.R & $16 /$ set & \multirow{4}{*}{ Note 3} \\
\hline & 161 kV 40MVAR SH.R & 18/set & \\
\hline & 161 kV 80MVAR SH.R & $21 /$ set & \\
\hline & 345 kV 100MVAR SH.R & $25 /$ set & \\
\hline \multirow{4}{*}{ GIS room E/S(+D/S) } & 345 kV GIS & 80/room & \multirow{4}{*}{ Note 4} \\
\hline & 161 kV GIS & 66/room & \\
\hline & $69 \mathrm{kV}$ GIS & 30/room & \\
\hline & $23 \mathrm{kV}$ GIS & 15/room & \\
\hline \multirow{2}{*}{ GIS room (D/S) } & 161 kV GIS & 30/room & \multirow{2}{*}{ Note 4} \\
\hline & $23 \mathrm{kV}$ GIS & 15/room & \\
\hline \multirow{6}{*}{$\mathrm{SC}$ room } & $69 \mathrm{kV} 43.2$ MVAR SC & $7.2+25 \times 3=82.2 / \mathrm{set}$ & $\begin{array}{c}\text { including } 3 \text { sets } \\
\text { of reactors }\end{array}$ \\
\hline & $69 \mathrm{kV} 28.8$ MVAR SC & $4.8+3.7 \times 3=15.9 / \mathrm{set}$ & $\begin{array}{c}\text { including } 3 \text { sets } \\
\text { of reactors }\end{array}$ \\
\hline & $69 \mathrm{kV} 18$ MVAR SC & $3.0+3.7 \times 3=14.1 /$ set & $\begin{array}{c}\text { including } 3 \text { sets } \\
\text { of reactors }\end{array}$ \\
\hline & $23 \mathrm{kV} 9000$ KVAR SC & $1.5+3.3 \times 3=11.4 /$ set & $\begin{array}{c}\text { including } 3 \text { sets } \\
\text { of reactors }\end{array}$ \\
\hline & 11 kV 6000 KVAR SC & $1.0+1.4 \times 6=9.4 / \mathrm{set}$ & $\begin{array}{c}\text { including } 3 \text { sets } \\
\text { of reactors }\end{array}$ \\
\hline & 11 kV 3000 KVAR SC & $0.5+1.4 \times 3=4.7 /$ set & $\begin{array}{c}\text { including } 3 \text { sets } \\
\text { of reactors }\end{array}$ \\
\hline \multirow{2}{*}{$\begin{array}{c}\text { Used cable } \\
\text { processing room } \\
\mathrm{E} / \mathrm{S}(+\mathrm{D} / \mathrm{S})\end{array}$} & $\begin{array}{c}345 \text { kV GIS+A.TR - } \\
\text { Cable }\end{array}$ & 110/room & \multirow{2}{*}{ Note 4} \\
\hline & $\begin{array}{c}161 \text { kV GIS + SH.R + } \\
\text { D.TR +23 KV GIS-Cable }\end{array}$ & 110/room & \\
\hline \multirow{2}{*}{$\begin{array}{c}\text { Used cable } \\
\text { processing room } \\
(\mathrm{D} / \mathrm{S})\end{array}$} & $\begin{array}{c}161 \mathrm{kV} \text { GIS+D.TR+23 kV } \\
\text { GIS - Cable }\end{array}$ & $45 /$ room & \multirow{2}{*}{ Note 4} \\
\hline & 23 kV GIS - Cable & 28/room & \\
\hline
\end{tabular}

Note 3: The calorific values of the transformer and reactor do not include the heat discharged from the radiator. If the radiator is placed indoors, its heat must be incorporated into the calculation of the ventilation volume. Before the company provides the calorific value of the radiator, the manufacturer should design the ventilation facility of the room by considering ten times the listed calorific value as the total capacity. Note 4 : The calorific value of the GIS equipment listed in this table and the cable in the used cable processing room is set with the specific equipment. If the number of equipment or the cable length is different, it should be separately adjusted. 
Table 3. Calorific values for transformers in the substation.

\begin{tabular}{cccccccccc}
\hline $\begin{array}{c}\text { The Self-Supply Transformer } \\
\text { Capacity in the Substation (KVA) }\end{array}$ & $\mathbf{5 0}$ & $\mathbf{1 0 0}$ & $\mathbf{2 0 0}$ & $\mathbf{3 0 0}$ & $\mathbf{5 0 0}$ & $\mathbf{1 0 0 0}$ & $\mathbf{1 5 0 0}$ & $\mathbf{2 0 0 0}$ \\
\hline The calorific value $(\mathrm{kW})$ & 1.2 & 2.3 & 4 & 5.5 & 8 & 15 & 20 & 25 \\
\hline
\end{tabular}

\subsubsection{Fan Power Calculation}

The power required by the fan is primarily increased or decreased according to the ventilation volume required by the ventilation system and the pressure loss of the system. The required ventilation volume can be obtained according to Equations (4)-(6), and the system pressure loss varies with different ventilation equipment and the speed of wind. The pressure loss of each ventilation device in the system must be listed in the calculation sheet for calculating the shaft power of the fan motor. Note that the calculation formula (8) is as follows:

$$
\mathrm{BHP}=\frac{\mathrm{Q} \times \mathrm{TSP} \times \mathrm{SF}}{6120 \times \mathrm{ESP}}
$$

BHP: Shaft power $(\mathrm{kW})$

Q: Ventilation volume (CMM)

TSP: System pressure loss (centimeter water column, mmAq or mmWG)

SF: Safety factor (1.2 or more)

ESP: Static fan efficiency (\%)

Considering factors such as an increase in the system pressure loss, the fan motor power should have a margin of $10 \%$ or more. If a belt-driven fan is used, the fan motor must have another margin of $3 \%$ or more to supply the required power loss. In air-conditioned places such as the control room, communication room, and electrical relay room, $\mathrm{CO}_{2}$ automatic fire-extinguishing equipment is required. According to the "Fire-fighting Installation Standard", a special fan equipment for removing the $\mathrm{CO}_{2}$ gas must be provided. The minimum ventilation volume should be calculated based on six or more times of ventilation per hour. In each machine room, the synthetic noise value of the fan should not exceed $82 \mathrm{dBA}$. The measurement height of the indoor noise should be $150 \mathrm{~cm}$ above the floor and the vicinity of the synthetic noise should be in higher places. The indoor noise of the fan-dedicated room may not be limited by the upper value of $82 \mathrm{dBA}$; however, the noise measured outside the fan's wall or door at a distance of $150 \mathrm{~cm}$ from the wall should not exceed $70 \mathrm{dBA}$, and the measurement height should be $120 \mathrm{~cm}$ above the building floor. Except for the above outdoor areas, the noise in the other places (such as ladders and workrooms) should not exceed $60 \mathrm{dBA}$; moreover, the measurement height should be $150 \mathrm{~cm}$ above the floor, close to the point where the synthetic noise is the highest. The synthetic noise value generated by all fans should not exceed $70 \mathrm{dBA}$ outside the building. This noise measurement should be near the center of the ventilation louver, and the point where the synthetic noise is higher and $150 \mathrm{~cm}$ away from the outer wall of the building. Moreover, the synthetic noise value of the fan on the roof should be $<70 \mathrm{dBA}$. The noise measurement position should be closest to the noise source on the parapet wall or at the point where the synthetic noise is the highest. The measurement height should agree with the noise source height. The operations of the transformer, reactor, $161 \mathrm{kV}$ GIS, and emergency generators can continuously generate larger noises; thus, silencers should be installed indoors or at the inlet/outlet openings or the building design should be used to achieve a sound-absorbing function that complies with the design guidelines and noise control standards. The fan types of models selected for use in the substation building listed below:

1. In-line fixed-load centrifugal fan: It is suitable for indoor use because it requires less space for configuration. It can be used as an exhaust fan or blower.

2. Rooftop louver-type fixed-load centrifugal fan: It is suitable for roof installation and can generally be used only as an exhaust fan. 
3. Conventional vortex-type fixed-load centrifugal fan: It is suitable for indoor or outdoor use but requires a large space for configuration. It can be used as either an exhaust fan or a blower.

To control the operation or stop the ventilation, all fans and their associated equipment must be equipped with an electromagnetic switch on their power circuit, and the electromagnetic switch selected must have appropriate overload, undervoltage, or under-equal protection for the fan motor. Furthermore, the ventilation system should be equipped with the following control devices:

(a) Timed automatic control: Each ventilation zone must be equipped with a timed automatic control facility to control the operation of the ventilation system. The timed control method should be determined according to the characteristics of each site. In the electromechanical equipment location with high calorific value (Table 2), in addition to the timed automatic control, the indoor ventilation facilities must be equipped with automatic temperature control such that the ventilation facilities can be automatically started and stopped according to the set temperature. (The temperature control switch should be separated, the controller should be placed in the room at a height of $1.5 \mathrm{~m}$ above the floor, the sensor should be placed $50 \mathrm{~cm}$ below the beam; however, the sensors in the transformer room, reactor room, and the $69 \mathrm{kV}, 161 \mathrm{kV}$ GIS room should be set at a height of $4.5 \mathrm{~m}$ above the floor.) The rest of the site may be exempted from such installations.

(b) On-site manual control: Each ventilation zone should be located next to its outdoor door. At least one place can be manually specified to manually start and stop the manual control switch of each area of the ventilation facilities; moreover, the area can be automatically ventilated for $5 \mathrm{~h}$ after the operation is manually started. If there is other automatic control, it should be restored to this automatic control state.

(c) Total monitoring panel: The ventilation system should be equipped with a total monitoring panel. The control panel of the ventilation equipment and the warning light number should be provided for monitoring on the panel and installed in the stairwell of the non-main entrance and exit on the first floor of the building.

\section{Materials and Methods}

In this section, we introduce the MOPSO intelligent optimization design of the substation ventilation system along with BIM modeling and confirm both cooling and ventilation performance of ANSYS FLUENT 18.0. This section is structured as follows. In Section 2.1, we discuss ways to simulate mixed ventilation and verify the design inside and outside the substation. In Section 2.2, we describe ways to use MOPSO for the optimization design of the ventilation inlet and outlet opening areas in the equipment room of the substation. In Section 2.3, we introduce methods to calculate synthetic noise. In Section 2.4, we introduce ways to use BIM to model the ventilation system of the substation. Finally, in Section 2.5, we introduce methods to use ANSYS FLUENT 18.0 for analysis and verify combined ventilation inside and outside the substation.

\subsection{Mixed Ventilation Simulation Analysis and Optimization Design Inside and Outside the Substation}

In the design stage, the purpose of indoor airflow simulation is to confirm and optimize the efficiency of the mechanical ventilation system using MOPSO optimization and numerical analysis, as well as confirm whether the short-circuit cycle occurs under the design conditions of the ventilation equipment for the main equipment space of this study is the basis for optimizing the mechanical ventilation design.

Based on CFD simulation analysis, we consider the outdoor natural wind and calculate the actual air volume of the fan when the ventilation systems in various functional spaces are operating together, the airflow organization and temperature distribution of each functional space in extreme conditions, as well as verify the ventilation system design such as the rationality of the airflow organization, 
fan selection, and indoor temperature distribution. Figure 1 shows the workflow of the optimization design analysis of the ventilation system in the substation. The main process is as follows:

1. MOPSO is used to calculate the optimized ventilation and outlet opening area of the equipment room.

2. Because we calculate the outdoor wind field of the building (the dominant wind conditions in summer), we can obtain the wind pressure distribution at the opening of the building shell and evaluate the natural ventilation conditions when the fan is not turned on.

3. Under the static wind condition, we calculate the indoor airflow organization and ventilation amount when the indoor fan exhausts.

4. We calculate the indoor airflow organization and ventilation volume under combined conditions of natural ventilation and mechanical ventilation.

5. Based on the above simulation, the optimization scheme is then proposed and confirmed.

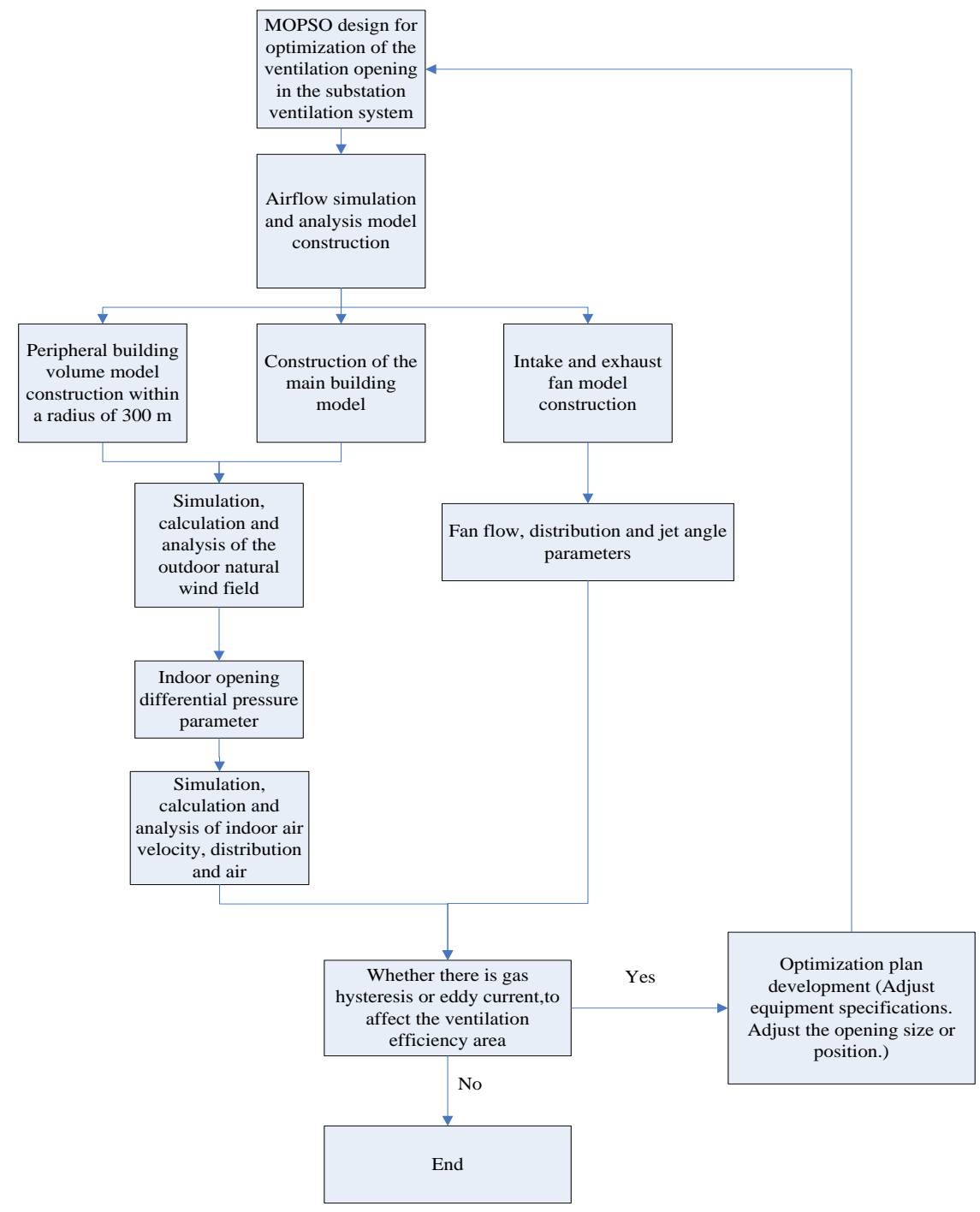

Figure 1. Flowchart of mixed ventilation simulation analysis and optimization design inside and outside the substation.

2.2. Optimization Design of the Ventilation Inlet and Outlet Opening Areas in the Equipment Room of the Substation Using MOPSO

The evolutionary calculation simulates the natural world of natural selection and survival of the fittest, and uses the parallel best search process to determine the solution for the optimal combination 
in several solution sets. The particle swarm optimization (PSO) algorithm [34-38] is primarily based on the group behavior of birds and fish. Each bird or fish in a group resembles a particle; moreover, its position and speed, adjusted by the adaptive function, is updated to a new position according to the direction range. The particle refers to the past successful experience (Pbest) and the current best particle in the group (Gbest), and then obtains the new speed and location according to a set of updated equations. Sporr et al. added a new parameter, the inertia weight $\omega$, to the original equation [3]. The particle velocity was updated $\omega$ and the parameter range decreased from 1.4 to 0.2 , and the appropriate range was found to be between 0.4 and 0.9 . The equation is updated as follows:

$$
\begin{gathered}
V_{i+1}=\omega V_{i}+C_{1} \operatorname{rand}\left(P_{i d}-X_{i}\right)+C_{2} \operatorname{rand}\left(P_{g d}-X_{i}\right) \\
X_{i+1}=X_{i}+V_{i}+1
\end{gathered}
$$

where $V_{i}$ is the original moving direction of particle $i$ and $X_{i}$ is its original position. The constants $c 1$ and $\mathrm{c} 2$ are learning factors set to 2 , rand represents the $(0,1)$ random number, $\mathrm{P}_{\mathrm{id}}$ is the best position in the individual search, and $\mathrm{P}_{\mathrm{gd}}$ is the best position in the group fitness value. Ke et al. [10] reported that the purpose of this inertia weight is to balance the abilities of global exploration and local search. According to the ventilation design process, both the inlet and outlet opening area required for the horsepower design value of the outlet system of the ventilation system is determined. Because there are multiple solutions to the ventilation system under the target value of the inlet and outlet opening wind speed, it is necessary to design the inlet opening area to determine the search range, as shown in Figure 2. Subsequently, we use the relation between the opening area of the inlet air and the static pressure, as shown in Equations (6) and (7), for the adaptive function calculation to determine the best air inlet static pressure. Moreover, it is possible to plan the venting area to determine the search range, as shown in Figure 3, and then use the relation between the opening area of the outlet and the horsepower of the exhaust fan, as shown in Equations (6)-(8), for the adaptive function calculation to determine the power of the best exhaust fan.

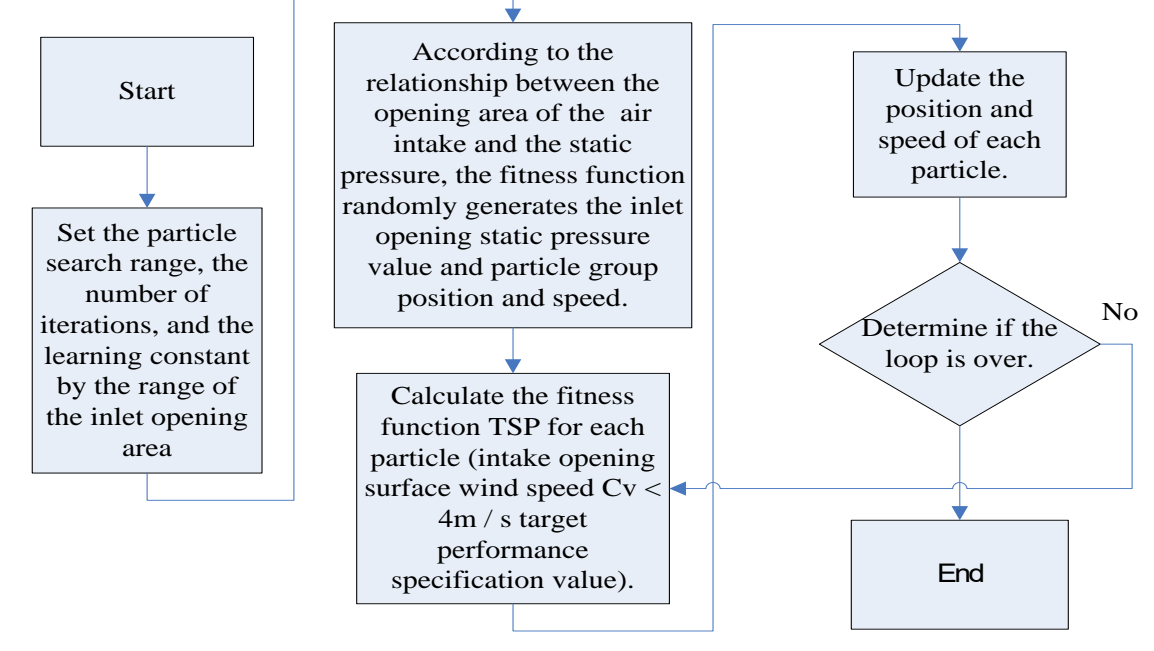

Figure 2. Optimized design flowchart for the equipment room inlet opening area and static pressure. 


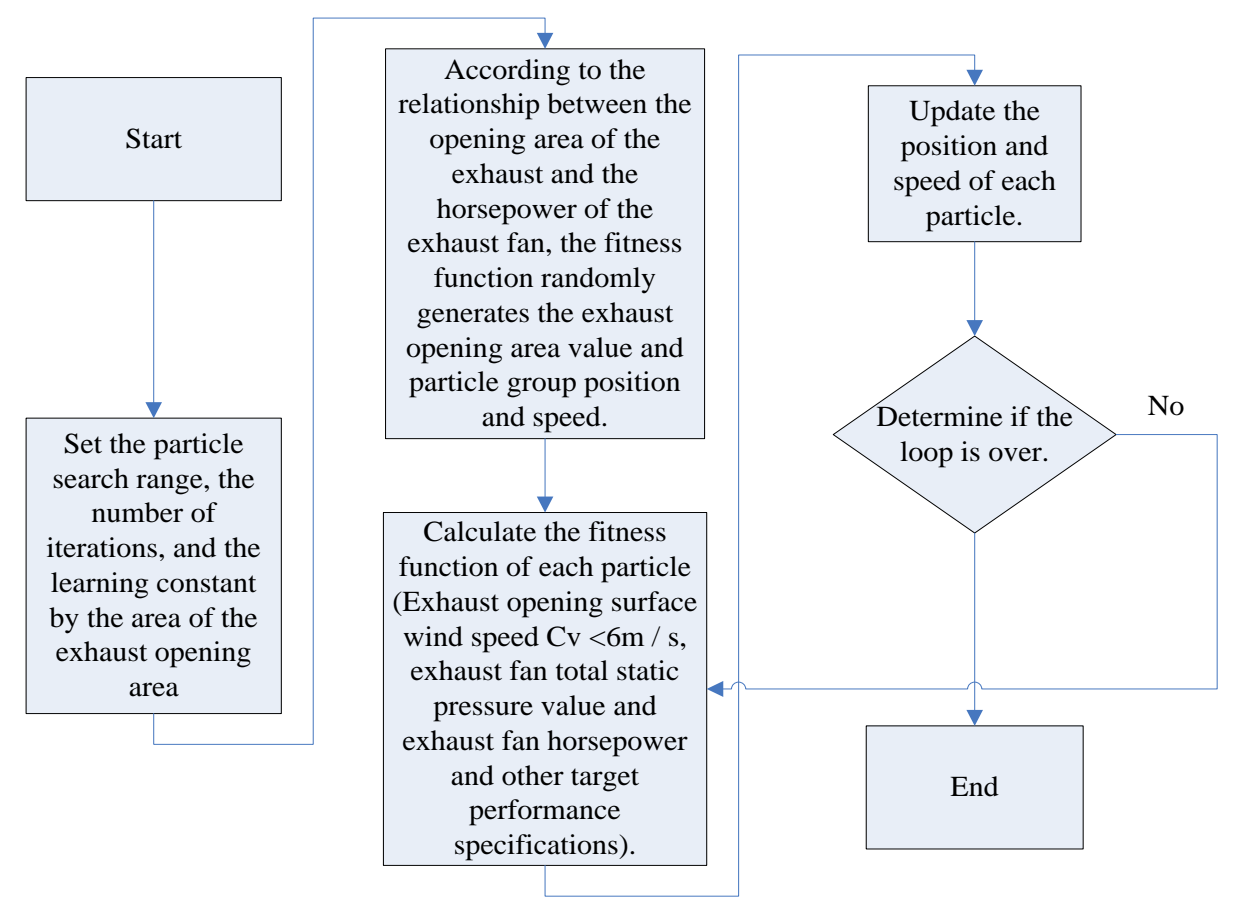

Figure 3. Optimized design flowchart for the equipment room outlet opening area and the exhaust fan horsepower.

\subsection{Synthetic Noise}

Synthetic noise quantification uses the equivalent continuous sound pressure level [39] for evaluation, which is a noise evaluation index recommended by ISO 1996 international standard. It is defined as the average energy value of the volume measured over a period of time and has been widely used by countries around the world. The $\mathrm{N}$ A-weighted sound pressure levels $\mathrm{L}_{\mathrm{eq}, \mathrm{n}}$ can calculate the corresponding equivalent level according to formula (11) as follows:

$$
\text { synthetic noise }=\text { Leq }=10 \log _{10}\left(\frac{1}{\mathrm{~N}} \sum_{\mathrm{t}=1}^{\mathrm{N}} 10^{\frac{\text { Leq, } \mathrm{n}}{10}}\right)
$$

\subsection{BIM}

BIM is defined as an architectural engineering information model composed of complete and sufficient information to support new product development management; it can be directly interpreted by computer applications. BIM helps assess the efficiency of energy use in the design phase [40-42]. Combined with a professional energy simulation software, BIM can accurately simulate the mechanical, electrical, and plumbing pipeline and indoor climate control as well as provide different design choices and suggestions to enhance performance and efficiency of buildings. To adapt to different climate-related changes, considerable equipment is used to maintain the indoor climate. For sustainable designs, maintaining the climate change adaptability through passive design or intelligent devices is important. BIM can estimate the carbon footprint during concept design, which will not only provide a practical solution for future low-carbon cities but also confirm the feasibility of low-carbon design and identify the carbon reduction potential during the construction phase or implementation. In addition to the embodied carbon emissions, further control of carbon emissions is an issue we should focus on. Moreover, we must continue to perform carbon reduction actions until carbon neutrality is achieved for sustainable development. In this section, the MOPSO optimization result parameters of each inlet and outlet opening area of the substation in Section 2.2 are used to construct the ventilation structure of the substation building using BIM and the surrounding structure of the substation. 


\subsection{ANSYS FLUENT 18.0}

ANSYS FLUENT version 18.0 was used for indoor ventilation calculation. It contains a wide range of physical models and can be used to simulate the flow, heat transfer, and reaction processes for industrial applications [43,44]. It is one of the most extensively used CFD simulation software for building ventilation. After establishing the indoor airflow analysis model in the substation, the design parameters of the exhaust fan, such as the flow rate, distribution, and jet angle, are used to simulate the air flow velocity, flow direction, and temperature distribution of each zone. Accordingly, we can determine whether there is an area for airflow hysteresis and eddy current to affecting the outlet gas efficiency.

\section{Result}

In this study, the 25 MVA main substation expansion project has three main floors, including one floor underground and two floors above the ground.

The primary functional space on the basement level of the building is the used cable processing room. The functional space on the ground floor includes the main transformer room, the GIS room, and the generator room. Furthermore, the functional space on the above-ground second floor includes the SC room, the fire equipment room, and the buffer room. Note that the substation adopts mechanical ventilation and each functional space is equipped with independent ventilation equipment without air-conditioning equipment. In Section 3.1, we simulate the ventilation using MOPSO, In Section 3.2, the optimized ventilation system in mopso for verifying.

\subsection{Optimization of the Ventilation System for MOPSO}

In this study, Matlab 2015b is used to simulate the relation between the inlet and outlet opening area of the ventilation system in the equipment room, the static pressure of the opening, and the horsepower of the exhaust fan under the double MOPSO (Figure 4). In the substation optimization results, in the B1F underground used cable processing room, the inlet opening area is $\sim 2.5 \mathrm{~m}^{2}$, the inlet opening static pressure is $\sim 0.49 \mathrm{mmaq}$, the outlet opening area is $\sim 2.9 \mathrm{~m}^{2}$, and the power of outlet opening exhaust fan is $\sim 0.803 \mathrm{Hp}$ while that of the exhaust fan is only 0.75 or $1 \mathrm{Hp}$. To satisfy the dynamic conditions, a power of $1 \mathrm{Hp}$ was selected. In the $1 \mathrm{~F} 23 \mathrm{kV}$ GIS room, the inlet opening area was $\sim 2.5 \mathrm{~m}^{2}$, the inlet opening static pressure was $\sim 0.1 \mathrm{mmaq}$, the outlet opening area was $2.8 \mathrm{~m}^{2}$, and the power of the outlet opening exhaust fan was $\sim 1.49 \mathrm{Hp}$ while that of the exhaust fan machine was only 1 or $075 \mathrm{Hp}$. To satisfy the dynamic conditions, two powers of $0.75 \mathrm{Hp}$ were selected. As for others in the equipment room, because the design already adopted a power of $0.5 \mathrm{Hp}$ or less for the minimum horsepower model of the exhaust fan, there was no planned double MOPSO for optimizing the outlet power.

The equipment room has been optimized by the MOPSO of the fan equipment. The benefit analysis of non-roof exhaust fan power reduction, the annual electricity cost of exhaust fan, and the equipment cost reduction of exhaust fan are shown in Tables 4-6, respectively. Moreover, when the power of the exhaust fan and the motor noise is reduced, the noise of the two exhaust fans in the equipment room will naturally decrease. For the natural environment of the surrounding community, it has the effect of achieving environmental protection and good neighborliness and complying with the world's green building energy- and carbon-saving. 


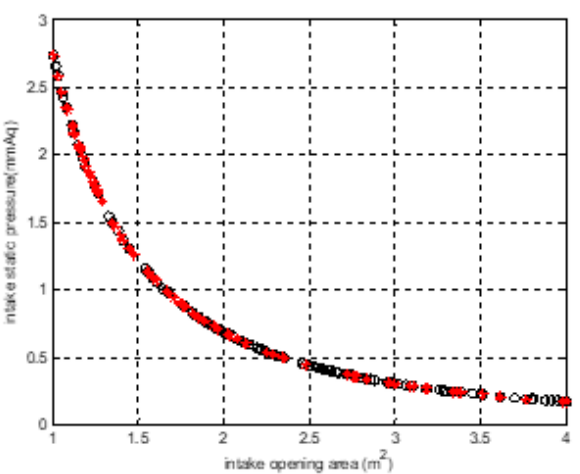

Optimized curve of the inlet opening area and inlet static pressure in the B1F used cable processing room

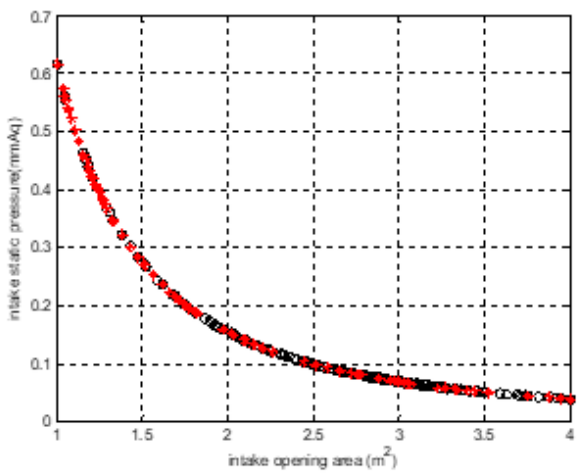

Optimized curve of the inlet opening area and inlet static pressure in the $1 \mathrm{~F} 23 \mathrm{kV}$ GIS room

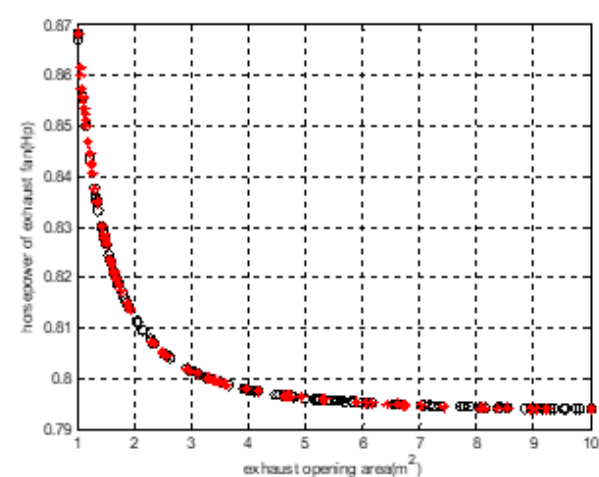

Optimized curve of the power and outlet opening area of exhaust fan in the B1F used cable processing room

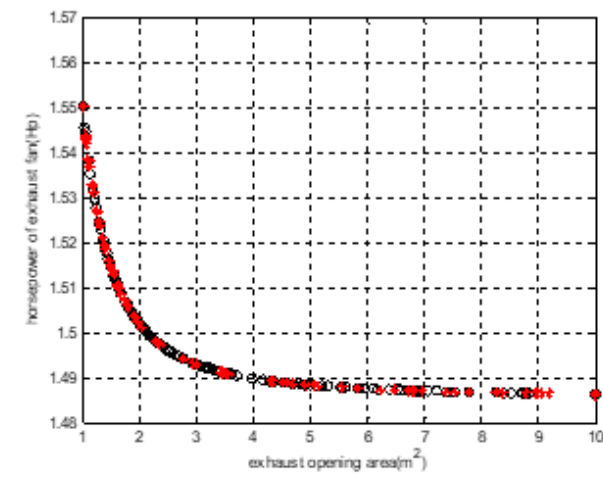

Optimized curve of the power and outlet opening area of exhaust fan in the $1 \mathrm{~F} 23 \mathrm{kV}$ GIS room

Figure 4. Dual MOPSO optimization simulation results in the substation (red stars represent the local best; black circles represent the global best).

Table 4. Benefit analysis of MOPSO optimization (roof fan).

\begin{tabular}{|c|c|c|}
\hline $\begin{array}{l}\text { Names of } \\
\text { Equipment Rooms }\end{array}$ & $\begin{array}{c}\text { Original Design Fan } \\
\text { Horsepower } \times \text { Number of Sets }\end{array}$ & $\begin{array}{l}\text { Ventilation System MOPSO-Optimized Fan } \\
\text { Horsepower } \times \text { Number of Sets (Red Box) }\end{array}$ \\
\hline $\begin{array}{l}\text { B1F Used Cable } \\
\text { Processing Room }\end{array}$ & $\begin{array}{c}1.5 \mathrm{Hp} \times 2(\text { synthetic noise }= \\
62 \mathrm{dBA}, \text { inlet opening area }= \\
1.62 \mathrm{~m}^{2}, \text { outlet opening area }= \\
\left.1.89 \mathrm{~m}^{2}\right)\end{array}$ & $\begin{array}{c}1 \mathrm{Hp} \times 2(\text { synthetic noise }=58 \mathrm{dBA}, \\
\text { inlet opening area }=2.5 \mathrm{~m}^{2}, \text { outlet opening } \\
\left.\text { area }=2.86 \mathrm{~m}^{2}\right)\end{array}$ \\
\hline $\begin{array}{l}\text { 1F No.4 main } \\
\text { transformer room }\end{array}$ & $0.5 \mathrm{Hp} \times 2$ & $0.5 \mathrm{Hp} \times 2$ \\
\hline 1F 23 kV GIS room & $\begin{array}{c}2 \mathrm{Hp} \times 1 \text { (synthetic noise }=64 \mathrm{dBA}, \\
\text { inlet opening area }=1.48 \mathrm{~m}^{2}, \\
\left.\text { outlet opening area }=0.69 \mathrm{~m}^{2}\right)\end{array}$ & $\begin{array}{c}0.75 \mathrm{Hp} \times 2(\text { synthetic noise }=62 \mathrm{dBA}, \\
\text { inlet opening area }=2.5 \mathrm{~m}^{2}, \text { outlet opening } \\
\left.\text { area }=2.75 \mathrm{~m}^{2}\right)\end{array}$ \\
\hline $1 \mathrm{~F}$ generator room & $0.5 \mathrm{Hp} \times 1$ & $0.5 \mathrm{Hp} \times 1$ \\
\hline $\begin{array}{l}\text { 2F Fire equipment } \\
\text { room }\end{array}$ & $0.5 \mathrm{Hp} \times 1$ & $0.5 \mathrm{Hp} \times 1$ \\
\hline 2F SC room & $0.5 \mathrm{Hp} \times 2$ & $0.5 \mathrm{Hp} \times 2$ \\
\hline 1F toilet & $132 \mathrm{~W} \times 1$ & $132 \mathrm{~W} \times 1$ \\
\hline
\end{tabular}

Because the ventilated roof exhaust fans are rated at three-phase $220 \mathrm{~V}$, the $60 \mathrm{~Hz}$ model has a minimum-rated power of $0.5 \mathrm{Hp}$. The main transformer room, generator room, fire equipment room, and SC room have the roof-type minimum-rated power fans; therefore, no optimization is required. The toilet has a single-phase $220 \mathrm{~V}$ non-roof fan. 
Table 5. Benefit analysis of annual electricity cost reduction in the MOPSO-optimized exhaust fan.

\begin{tabular}{ccc}
\hline $\begin{array}{c}\text { Names of } \\
\text { Equipment } \\
\text { Rooms }\end{array}$ & $\begin{array}{c}\text { Annual Electricity Bill of the Original } \\
\text { Design Fan (Fixed Value of kWh } \\
\text { Consumed by the Fan Each Year }+ \\
\text { Power Consumption of the Fan during } \\
\text { the Summer Owing to Extremely High } \\
\text { Indoor Temperature + Standby Power } \\
\text { Consumption) }\end{array}$ & $\begin{array}{c}\text { MOPSO-Optimized Annual Electricity } \\
\text { Bill (Fixed Value of kWh Consumed by } \\
\text { the Fan Each Year + Power } \\
\text { Consumption of the Fan during the } \\
\text { Summer Owing to Extremely High } \\
\text { Indoor Temperature + Standby Power } \\
\text { Consumption) }\end{array}$ \\
\hline $\begin{array}{c}\text { B1F used cable } \\
\text { processing } \\
\text { room } \\
1 F 23 \mathrm{kV} \text { GIS } \\
\text { room }\end{array}$ & $\sim \$ 60 \mathrm{USD}(1.5 \mathrm{Hp} \times 2)$ & $\sim 40 \mathrm{USD}(1 \mathrm{Hp} \times 2)$ \\
& $\sim 40 \mathrm{USD}(2 \mathrm{Hp} \times 1)$ & $\sim 30 \mathrm{USD}(0.75 \mathrm{Hp} \times 2)$ \\
\hline
\end{tabular}

Table 6. Benefit analysis of equipment cost reduction in the MOPSO-optimized exhaust fan.

\begin{tabular}{ccc}
\hline $\begin{array}{c}\text { Names of Equipment } \\
\text { Rooms }\end{array}$ & $\begin{array}{c}\text { Original Design Fan } \\
\text { Horsepower Price }\end{array}$ & $\begin{array}{c}\text { MOPSO-Optimized Fan } \\
\text { Horsepower Price }\end{array}$ \\
\hline $\begin{array}{c}\text { B1F used cable } \\
\text { processing room }\end{array}$ & $\sim 8928$ USD $(1.5 \mathrm{Hp} \times 2)$ & $\sim 7652$ USD $(1 \mathrm{Hp} \times 2)$ \\
1 F $23 \mathrm{kV}$ GIS room & $\sim 7652$ USD $(2 \mathrm{Hp}=1 \mathrm{Hp} \times 2)$ & $\sim 3794 \mathrm{USD}(0.75 \mathrm{Hp} \times 2)$ \\
& $2019 / 7 / 3$ Exchange Rate: $1 \mathrm{USD}=31.365 \mathrm{NT}$ \\
\hline
\end{tabular}

\subsection{The Ventilation System for Verification}

For the BIM of the substation to be as close as possible to the real outdoor atmospheric environment, the external overall calculation area is expanded further and the overall calculation area has dimensions of $1000 \times 500 \times 100 \mathrm{~m}^{3}$. Figure 5 shows the architectural model of the local area and the model of the overall calculation area. For the calculated project building, the detailed building structure is considered and the location area of the air outlet is separately divided. Note that for mesh division, Integrated Computer Engineering and Manufacturing-CFD is used. Considering the calculation accuracy and calculation time, the hexahedral structured mesh and tetrahedral unstructured mesh are used for the division. Because of the small size of the local area, such as the air port of the project building, the area mesh with a small local size is encrypted. The complex structure of the area near the project building is difficult to realize because of the fully structured grid of the local area; thus, for the surrounding area of the building, an encrypted tetrahedral mesh is used and a structured hexahedral mesh is used in the surrounding area of the building. For the area near the ground, considering the wind speed gradient of the atmospheric boundary layer, the grid of the ground area is encrypted. Moreover, the total number of grids is 7.5 million, as shown in (Figure 6). In 2018, the dominant wind direction of the substation area during summer and the whole year was the north wind, and the average wind speed in June, July, and August 2018 was $2.83 \mathrm{~m} / \mathrm{s}$. Therefore, the north wind direction is adopted for the calculation, and a wind speed of $2.83 \mathrm{~m} / \mathrm{s}$ is used for analysis the condition of the calculation domain; furthermore, the distribution of the atmospheric wind speed boundary layer is considered. 


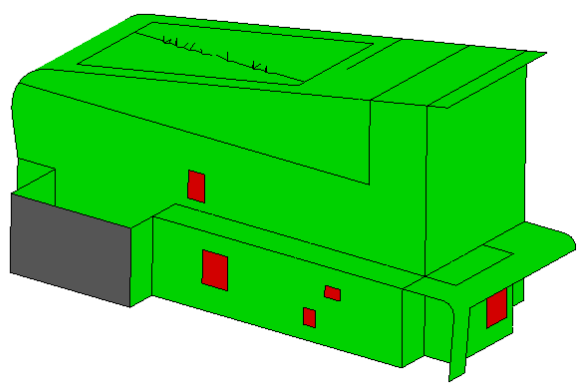

Local area model diagram

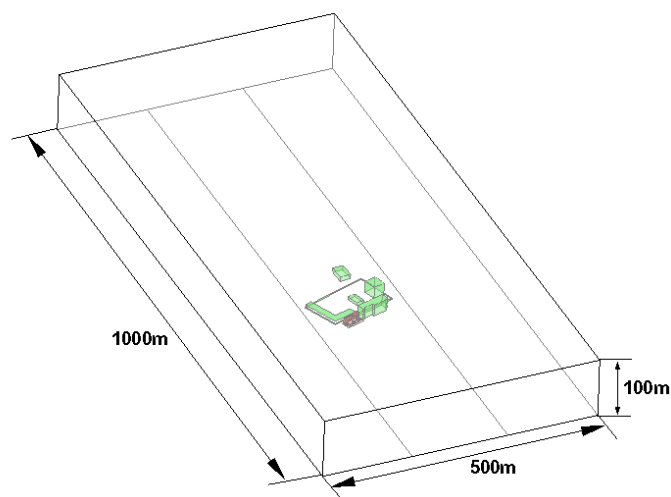

Outdoor wind field analysis chart

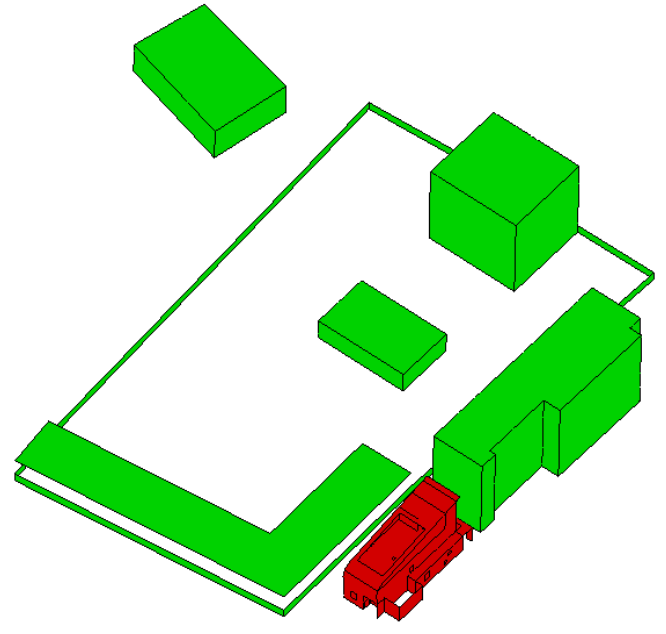

Overall area model diagram

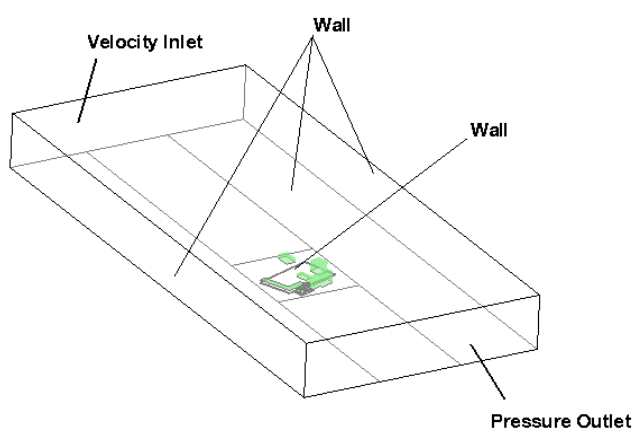

Analysis domain boundary condition chart

Figure 5. Architectural model of the outdoor local area and the model of the overall calculation area.

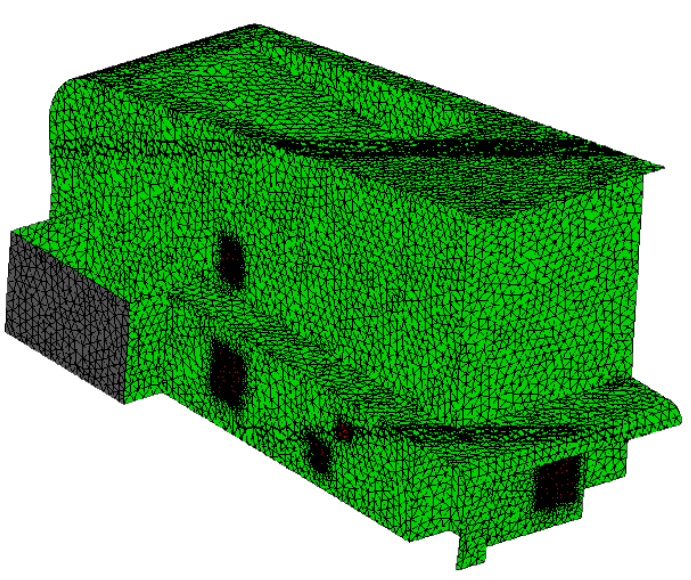

Local meshing results of the building

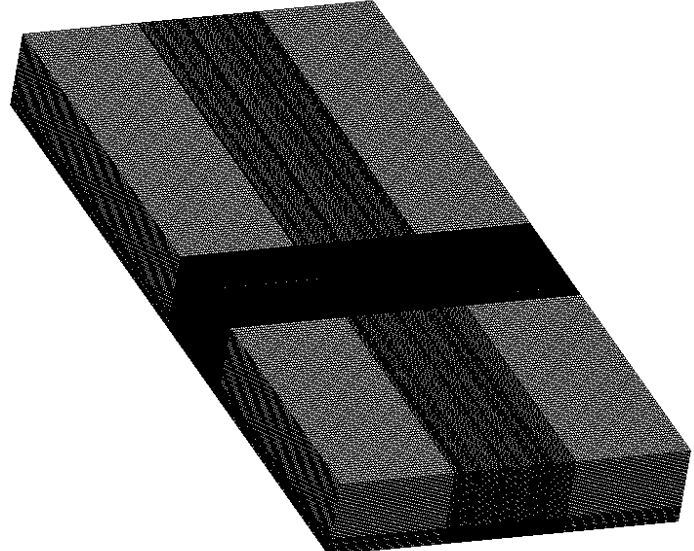

Overall area meshing results

Figure 6. Grid analysis of local and overall areas of outdoor buildings.

By repeated calculations using ANSYS FLUENT 18.0, the velocity and pressure fields of the whole calculation region were obtained. Figure 7 shows the velocity distribution and velocity vector at a height of $3 \mathrm{~m}$ around the building. The wind speed in the windward direction of the building is 
deflected because it is affected by the obstruction of the substation building. Furthermore, the wind speed in the windward direction or on the north side of the building is $\sim 1.5 \mathrm{~m} / \mathrm{s}$, whereas that in the leeward or on the south side is $0.6 \mathrm{~m} / \mathrm{s}$ or less. On the south side of the building, there is a recirculation zone, which facilitates the formation of a large ventilation pressure difference between the windward and leeward sides of the building. Figure 7 shows the surface pressure distributions of the windward and leeward sides of the building. The wind pressure on the windward side of the building is $0.0-2.0 \mathrm{~Pa}$, while that on the leeward side of the building is between -1.5 and $-1.0 \mathrm{~Pa}$. Note that the top of the building is in the negative-pressure zone, and the exhaust fan is primarily located at the top. Therefore, for mechanical ventilation, the arrangement of the building air port and the fan is beneficial to the use of the building surface pressure difference formed by the outdoor wind field.

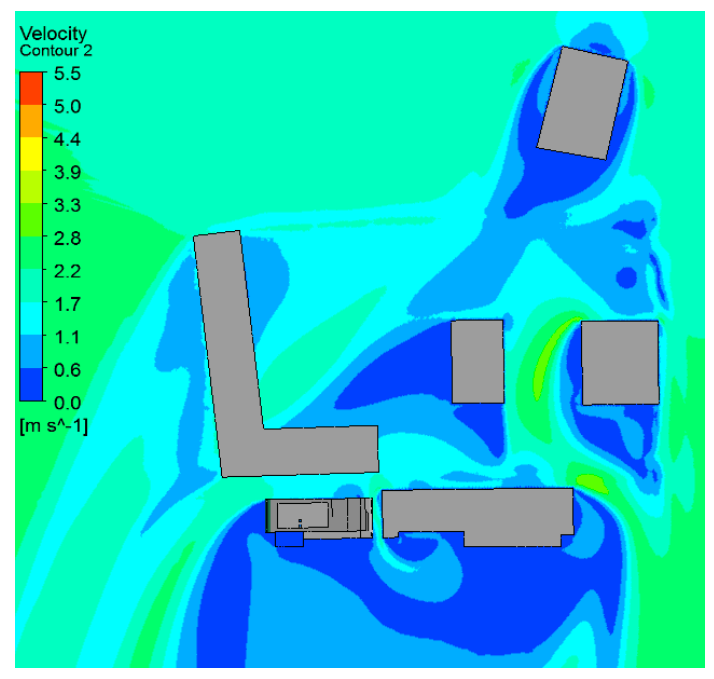

Speed distribution around the building

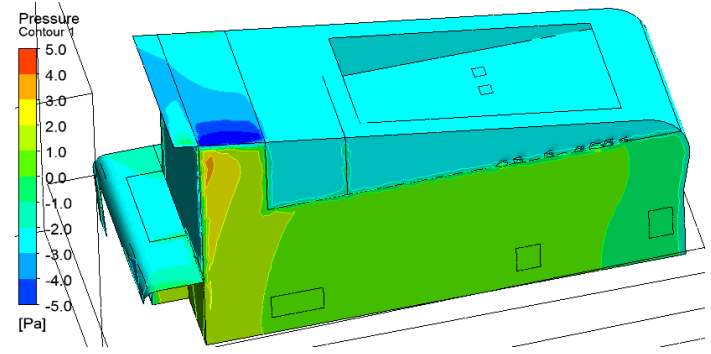

Windward pressure on the windward side of the building

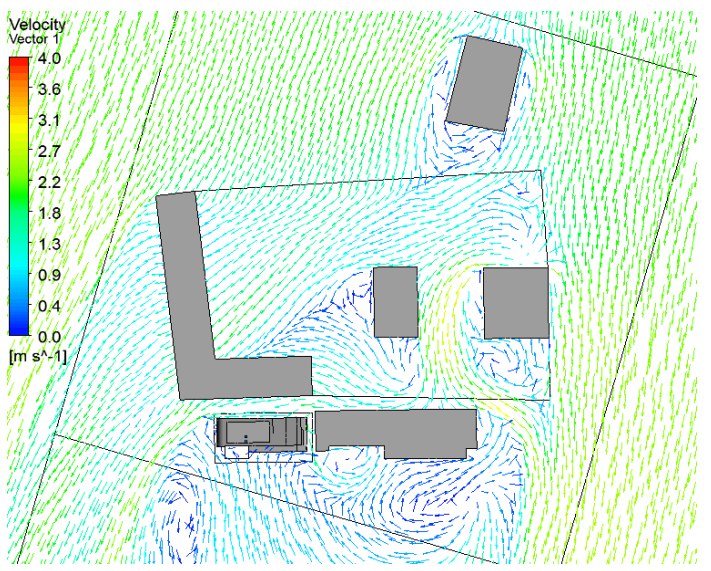

Velocity vector distribution around the building

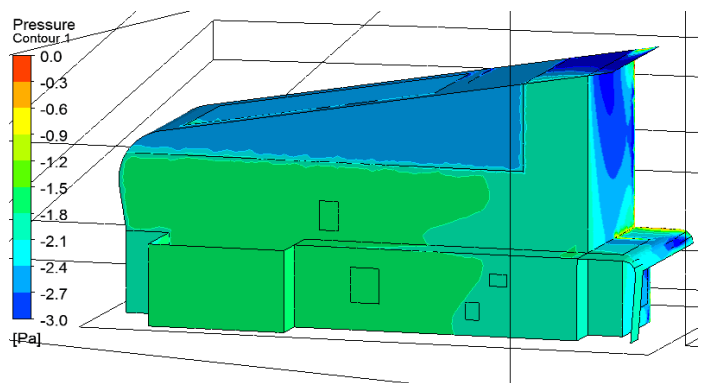

Windward pressure on the leeward side of the building

Figure 7. Analysis of the outdoor wind speed and wind pressure outside the building.

Note that the pressure on the ventilation opening and the exit of the exhaust fan is evaluated. Table 7 shows the static pressure of each air port, and the outlets of the roof fans are all under negative pressure. Except for the air pressure at the outlet of the main transformer room and the toilet outlet with the absolute value of $<0.5 \mathrm{~Pa}$, the absolute values of the air pressure at the remaining air ports are $>0.5 \mathrm{~Pa}$, which is beneficial to natural ventilation in summer and the transitional season. Note that the wind pressure calculation results of each air port will be used as the boundary conditions for indoor ventilation calculation; moreover, in combined operations, it used to calculate the airflow organization with the indoor mechanical outlet and outdoor natural wind. 
Table 7. Building vent pressure calculation results.

\begin{tabular}{|c|c|c|c|}
\hline Serial No. & $\begin{array}{l}\text { Air Port (Fan) } \\
\text { Code }\end{array}$ & Air Port Location & Pressure (Pa) \\
\hline Vent 1 & EAAL-2 & Outlet of the generator room & -1.82 \\
\hline Vent 2 & EAAL-1 & Outlet of the generator room & -1.82 \\
\hline Vent 3 & EAL-3 & Outlet of the GIS room & -1.65 \\
\hline Vent 4 & Louver on the door & $\begin{array}{c}\text { Outlet of the used cable processing room in the } \\
\text { basement }\end{array}$ & -1.85 \\
\hline Vent 5 & EAL-1 & $\begin{array}{c}\text { Outlet of the used cable processing room in the } \\
\text { basement }\end{array}$ & -1.77 \\
\hline Vent 6 & EAL-4 & $\begin{array}{c}\text { Outlet of the used cable processing room in the } \\
\text { basement }\end{array}$ & -0.57 \\
\hline Vent 7 & IAAL-1 & Outlet of the main transformer room & 0.30 \\
\hline Vent 8 & IAAL-2 & $\begin{array}{c}\text { Air inlet of the main transformer room and the } \\
\text { generator room }\end{array}$ & 0.81 \\
\hline Vent 9 & EAL-3 & Outlet of the toilet & 0.41 \\
\hline Vent 10 & IAL-2 & $\begin{array}{c}\text { Air inlet of the used cable processing room in the } \\
\text { basement }\end{array}$ & 1.25 \\
\hline Vent 11 & IAL-1 & $\begin{array}{c}\text { Air inlet of the used cable processing room in the } \\
\text { basement }\end{array}$ & -2.58 \\
\hline Vent 12 & IAL-3 & $\begin{array}{c}\text { Air inlet of the SC room and the fire equipment } \\
\text { room }\end{array}$ & -1.68 \\
\hline Vent 13 & EF-02 & Outlet of the main transformer room & -2.52 \\
\hline Vent 14 & EF-02 & Outlet of the main transformer room & -2.45 \\
\hline Vent 15 & EF-05 & Outlet of the fire equipment room & -2.59 \\
\hline Vent 16 & EF-06 & Outlet of the SC room & -2.59 \\
\hline Vent 17 & EF-06 & Outlet of the SC room & -2.59 \\
\hline
\end{tabular}

The indoor ventilation model is developed, and a three-dimensional (3D) model of the building interior structure and ventilation system is established based on the building structure and ventilation system drawings. Furthermore, in the calculation area, independent enclosed spaces, such as buffer rooms and toilet areas with only a single outlet, are not considered. Figure 8 shows the 3D model of the building's interior. Considering the more complicated indoor structural forms of air ports, fans, and equipment in the building and the large span of different structures when meshing, a complete tetrahedral unstructured grid is used and a grid encryption method is adopted for local areas such as an air port; moreover, the total number of grids is 6.5 million. Figure 9 shows the meshing results. According to the boundary condition and type settings, the boundaries of the model include exterior wall, floor, interior ventilation opening of adjacent rooms, ventilation opening on the exterior wall, equipment surface, and fan. Table 8 lists the condition and type settings of each boundary. Under the condition of outdoor natural wind, the indoor airflow structure is simulated only under the condition that the indoor ventilator is turned on; moreover, the indoor airflow organization is simulated under the condition that the indoor ventilator is turned on with outdoor wind in combined operations. Both calculation models consider the thermal calculations, outdoor thermal parameters, and heat dissipation of the indoor equipment. In these settings, the performance parameters of the selected fan, the resistance characteristics of the air inlet, and the outlet, the thermal conditions of the wall and the heat dissipation of the equipment are considered. By calculating the ventilation quantity statistics, the air volume of each exhaust fan is obtained and compared with the rated air volume of the fan. Moreover, we determine whether the fan model selected meets the requirements. Regarding the conditions in which only the mechanical outlet is available and the mechanical outlet is combined with natural ventilation, the simulation results of the outlet air volume of the fan are shown in Table 9. Note that the actual outlet volume of the exhaust fan is higher than the rated air volume of the fan. Considering the increase in the resistance of the filter during operation time, the current fan model meets the design requirements. Under the condition where only the outdoor natural wind is available, the outlet air volume of the exhaust fan is slightly higher than that under the condition that the outdoor 
wind in summer prevails without considering the natural wind, where the fan outlet is promoted, but the effect is not obvious.

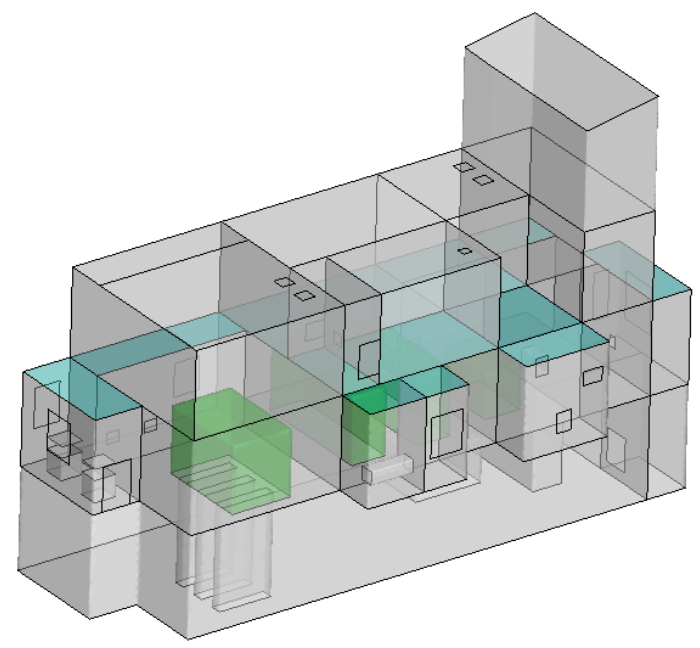

Figure 8. Perspective view of three-dimensional model of project interior space.
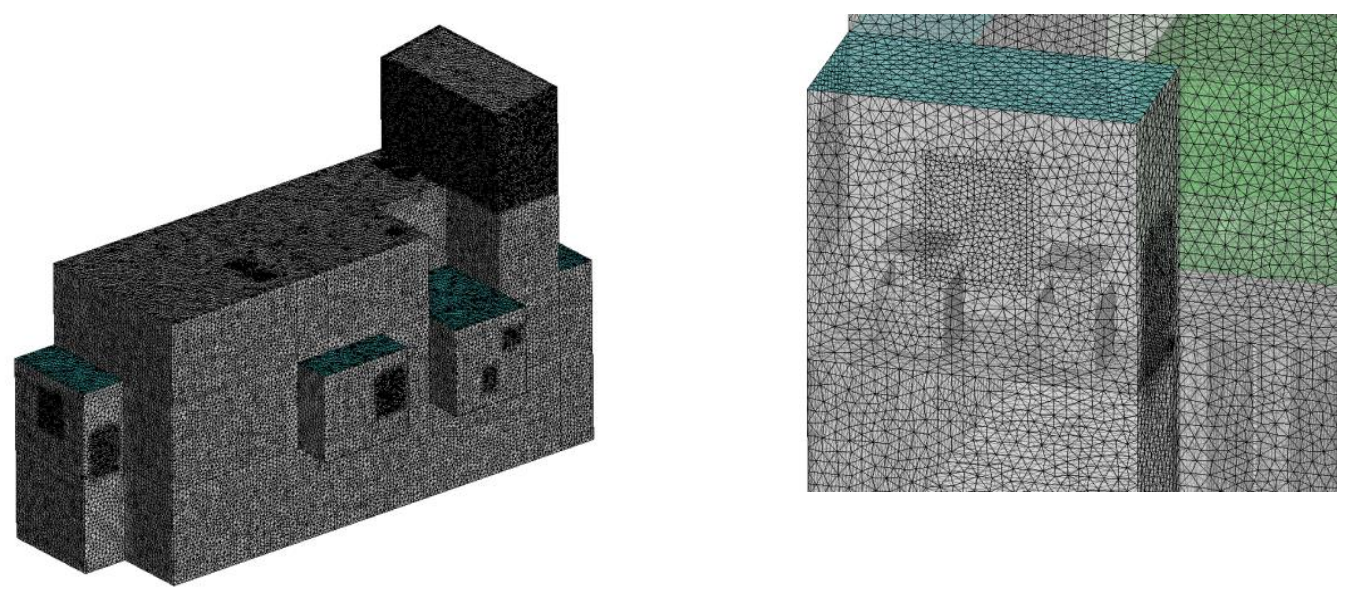

Figure 9. Grid analysis of the overall area inside the building. 
Table 8. Boundary conditions settings.

\begin{tabular}{|c|c|c|c|c|c|}
\hline Serial No. & Boundary & Boundary Conditions & \multicolumn{3}{|c|}{ Specific Settings } \\
\hline 1 & $\begin{array}{l}\text { Exterior } \\
\text { wall }\end{array}$ & Wall & \multicolumn{3}{|c|}{$\begin{array}{l}\text { For the third type of boundary conditions, considering the solar radiation, the corresponding air temperature is } \\
45^{\circ} \mathrm{C} \text {, the wall heat transfer rate is } 18 \mathrm{~W} /\left(\mathrm{m} 2 \cdot{ }^{\circ} \mathrm{C}\right) \text {, and the wall thermal conductivity is } 2.05 \mathrm{~W} /\left(\mathrm{m} \cdot{ }^{\circ} \mathrm{C}\right) \text {. }\end{array}$} \\
\hline 2 & $\begin{array}{l}\text { Interior } \\
\text { wall }\end{array}$ & Coupled wall & & & \\
\hline 3 & Air inlet & Inlet vent & \multirow{2}{*}{\multicolumn{3}{|c|}{$\begin{array}{l}\text { According to the air inlet resistance coefficient, the relation between the air inlet resistance and air volume is set. } \\
\text { Moreover, the air inlet pressure is set to } 0 \mathrm{~Pa} \text { for the independent operation condition of the fan, and the joint } \\
\text { operation condition is set according to the calculation result of the outdoor flow field. } \\
\text { According to the resistance coefficient of the outlet, the relation between the resistance of the outlet and the air } \\
\text { volume is set. Moreover, the pressure of the outlet is set, the inlet pressure of the independent operating condition } \\
\text { of the fan is } 0 \mathrm{~Pa} \text {, and the combined operating condition is set according to the calculation result of the outdoor } \\
\text { flow field. }\end{array}$}} \\
\hline 4 & Air outlet & Outlet vent & & & \\
\hline 5 & $\begin{array}{l}\text { Equipment } \\
\text { surface }\end{array}$ & Wall & \multicolumn{3}{|c|}{ The boundary is at a constant temperature, whereas the surface temperature is $45^{\circ} \mathrm{C}$. } \\
\hline 6 & Fan & Fan & \multirow{2}{*}{\multicolumn{3}{|c|}{$\begin{array}{l}\text { The fan performance parameters are set according to the provided performance curve. } \\
\text { According to the resistance characteristics of the indoor ventilation opening, the setup parameters of the porous } \\
\text { medium are calculated and the resistance characteristics of the medium surface are kept consistent with the } \\
\text { resistance coefficient of the ventilation opening. }\end{array}$}} \\
\hline 7 & $\begin{array}{l}\text { Indoor air } \\
\text { port }\end{array}$ & Porous jump & & & \\
\hline Serial No. & Fan Code & Outlet Area & Rated Air Volume $\left(\mathrm{m}^{3} / \mathrm{min}\right)$ & Mechanical Outlet (m³/min) & $\begin{array}{l}\text { Mechanical Outlet + Natural Wind } \\
\qquad\left(\mathrm{m}^{3} / \mathrm{min}\right)\end{array}$ \\
\hline 1 & EF-01 & Used cable processing room & 200 & 209 & 210 \\
\hline 2 & EF-01 & \multirow{2}{*}{ Used cable processing room } & 200 & 204 & 204 \\
\hline 3 & EF-02 & & 60 & 65 & 65 \\
\hline 4 & EF-02 & Main transformer room & 60 & 64 & 65 \\
\hline 5 & EF-03 & $23 \mathrm{kV}$ GIS room & 95 & 97 & 98 \\
\hline 6 & EF-04 & Generator room & 60 & 67 & 68 \\
\hline 7 & EF-05 & Fire equipment room & 20 & 27 & 28 \\
\hline 8 & EF-06 & SC room & 60 & 66 & 66 \\
\hline 9 & EF-06 & $\mathrm{SC}$ room & 60 & 66 & 66 \\
\hline
\end{tabular}


For indoor flow field analysis, the analysis of two different flow field conditions is conducted to examine whether the indoor air inlet and outlet organization is reasonable and whether the existence of a short circuit and local wind speed is unreasonable. For the convenience of analysis, the cross-section and longitudinal section of the building are determined from a certain floor height. Figure 10 shows the cross-sectional position; it is $2 \mathrm{~m}$ from the floor. Note that the two longitudinal sections can completely capture all functional spaces. Under the conditions where only the mechanical outlet is available and where the mechanical outlet and natural wind are both available, the wind speed analysis in the basement, the ground floor, and the second floor at a height of $2 \mathrm{~m}$ from the ground are shown in Figures 11 and 12, respectively. From the air inlet to air outlet, there is no short circuit in the main streamline structure; however, there are additional local eddy currents.

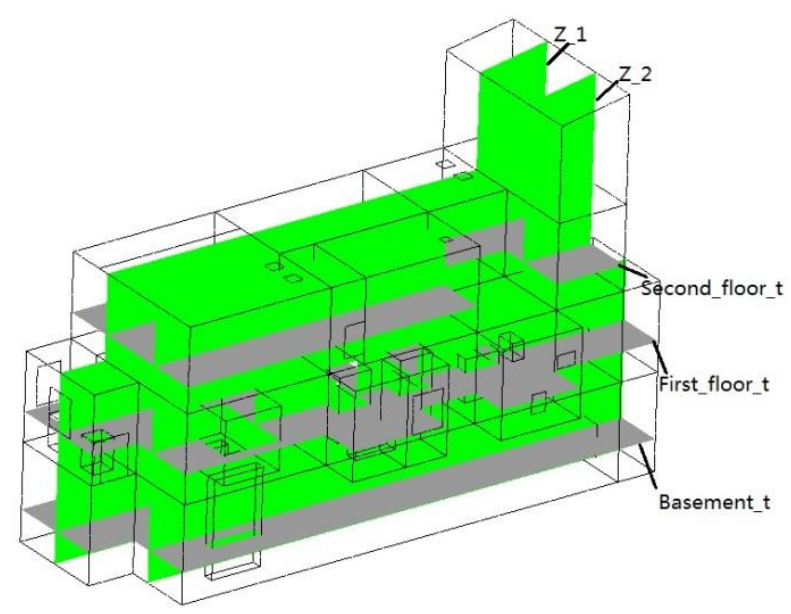

Figure 10. Schematic of the section positions for result analysis.

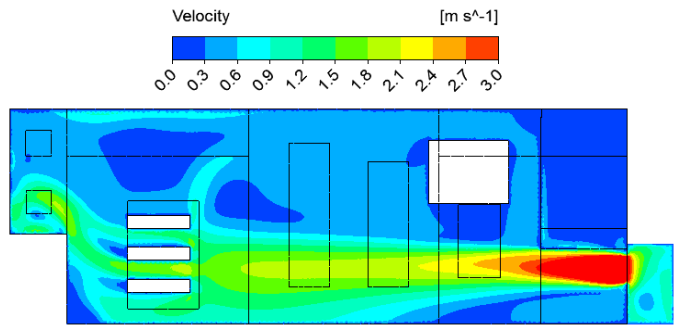

Mechanical outlet - basement - height: $2.0 \mathrm{~m}$ from the floor wind speed gradation map

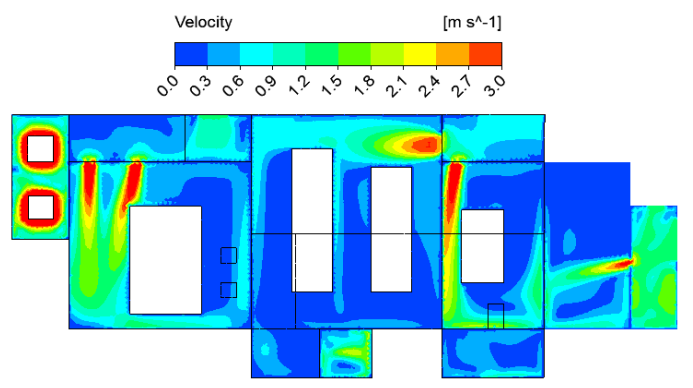

Mechanical outlet - 1st floor - height: $2.0 \mathrm{~m}$ from the floor wind speed gradation map

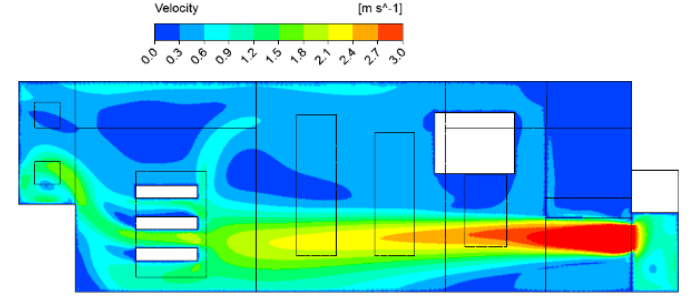

Wind speed vector distribution with mechanical outlet and outdoor natural wind in combined operations - basement height: $2.0 \mathrm{~m}$ from the floor - wind speed gradation map

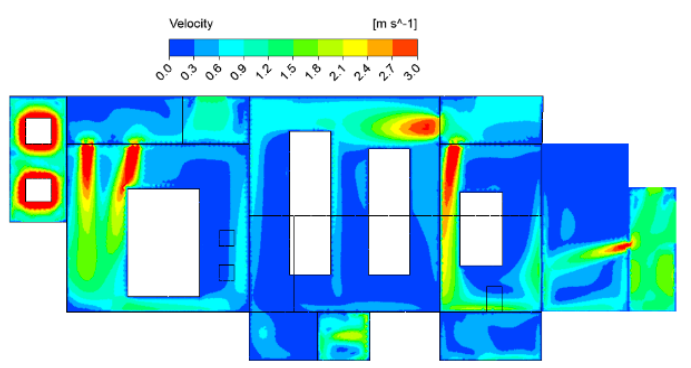

Wind speed vector distribution with mechanical outlet and outdoor natural wind in combined operations - 1st floor height: $2.0 \mathrm{~m}$ from the floor - wind speed gradation map

Figure 11. Cont. 


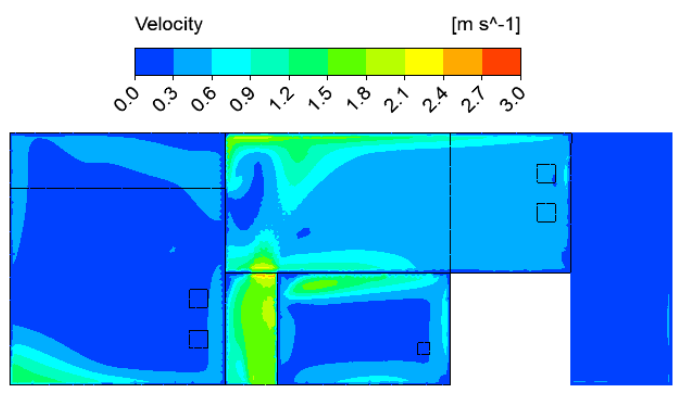

Mechanical outlet - 2nd floor - height: $2.0 \mathrm{~m}$ from the floor wind speed gradation map

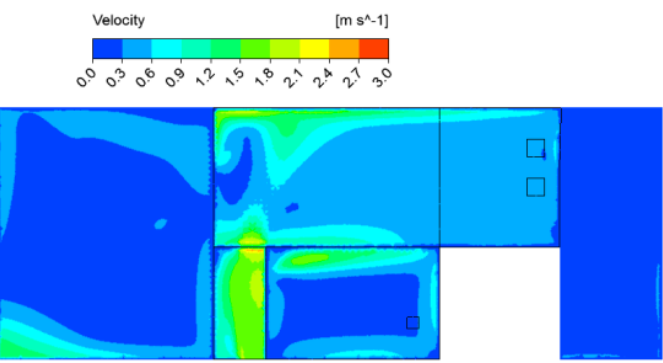

Wind speed vector distribution with mechanical outlet and outdoor natural wind in combined operations - 2nd floor height: $2.0 \mathrm{~m}$ from the floor - wind speed gradation map

Figure 11. Wind speed gradient distributions based on mechanical outlet or mechanical outlet + outdoor natural wind.

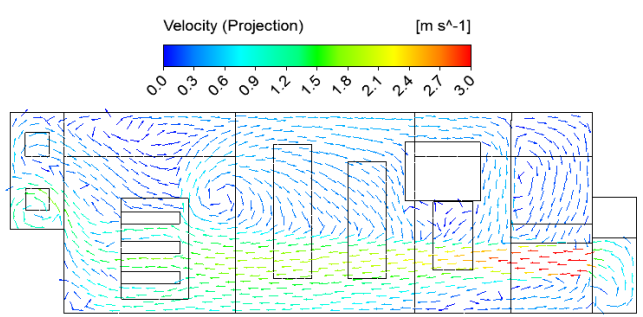

Wind speed vector distribution of mechanical outlet basement at a height of $2.0 \mathrm{~m}$ from the floor

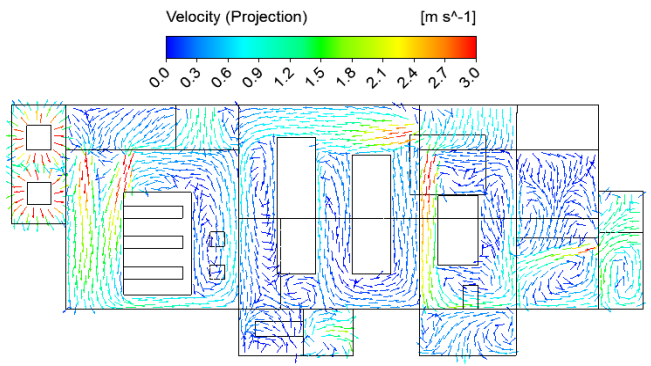

Wind speed vector distribution of mechanical outlet - 1st floor at a height of $2.0 \mathrm{~m}$ from the floor

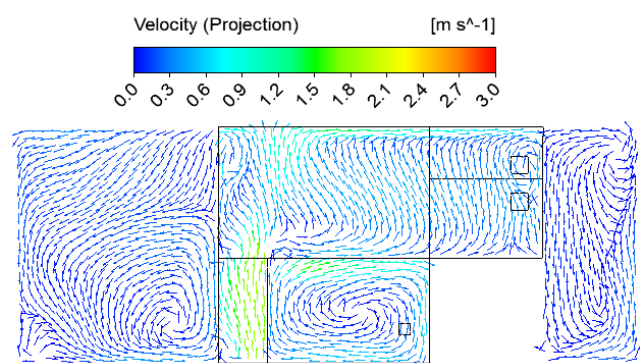

Wind speed vector distribution of mechanical outlet - 2nd floor at a height of $2.0 \mathrm{~m}$ from the floor

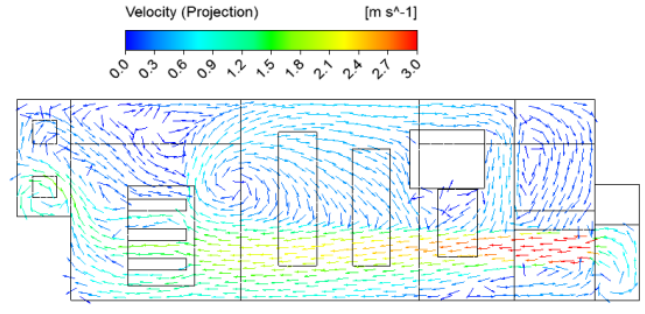

Wind speed vector distribution with mechanical outlet and outdoor natural wind in combined operations - basement at a height of $2.0 \mathrm{~m}$ from the floor

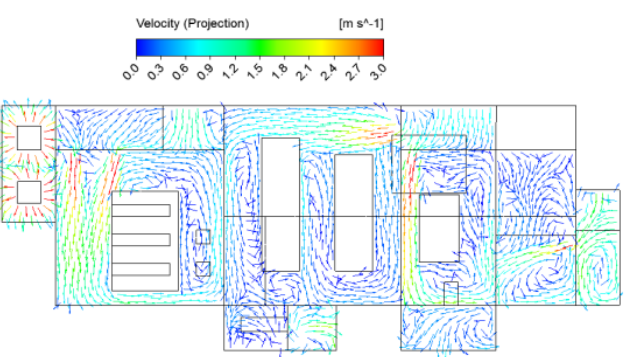

Wind speed vector distribution with mechanical outlet and outdoor natural wind in combined operations - 1st floor at a height of $2.0 \mathrm{~m}$ from the floor

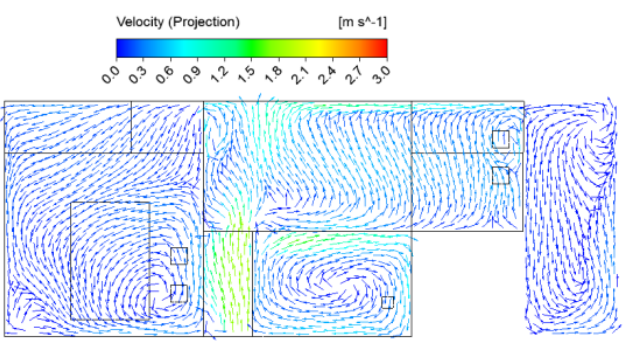

Wind speed vector distribution with mechanical outlet and outdoor natural wind in combined operations - 2nd floor at a height of $2.0 \mathrm{~m}$ from the floor

Figure 12. Wind speed vector distributions based on mechanical outlet or mechanical outlet + outdoor natural wind. 
The results of indoor average temperature analysis under two conditions in the room are used to calculate the average temperature in different spaces of the room (Table 10). At an outdoor temperature of $36^{\circ} \mathrm{C}$, the indoor temperature is up to $38.3^{\circ} \mathrm{C}$ and the design of the air volume meets the indoor heat dissipation requirements. On the first floor, the $23 \mathrm{kV}$ GIS room and the main transformer room have the highest temperature. Under the conditions where mechanical outlet and natural wind are both available, only the temperature of the used cable processing room is slightly lower than that in the case where only the mechanical outlet is available; moreover, the indoor average temperatures under the other two sets of working conditions are the same. Figure 13 shows the indoor temperature distribution under the mechanical outlet conditions, the temperature at a height of $2.0 \mathrm{~m}$ from the floor on different floors, and the temperature distribution of the overall longitudinal sections of the building. Because the basement has no heat-generating equipment and the surrounding wall is underground, it is less affected by the outdoor air temperature and solar radiation; therefore, the indoor temperature is lower overall. The overall temperature of the ground floor and the second floor is higher than that of the basement. The $23 \mathrm{kV}$ GIS room on the ground floor has a large calorific value of the device; therefore, the indoor temperature is relatively high. The longitudinal section's temperature distribution shows that the upper part of the stairwell is at a high temperature of up to $40^{\circ} \mathrm{C}$ because of the buoyancy of the rising hot air flow; however, the upper part of the stairwell is an enclosed space where hot air accumulates, resulting in a higher temperature in this area. We may consider adding a vent to the top of the stairwell or adding the ventilation louver on the door leading to the outside balcony at the top of the stair, which can both reduce the temperature in the top of the stairwell and use the chimney effect of the stairwell to form a higher hot-pressure ventilation effect, thus increasing the amount of natural ventilation.

Table 10. Indoor space average temperature analysis results under two conditions.

\begin{tabular}{|c|c|c|c|c|}
\hline \multirow{2}{*}{$\begin{array}{l}\text { Serial } \\
\text { No. }\end{array}$} & \multirow[t]{2}{*}{ Space Function } & \multirow{2}{*}{$\begin{array}{c}\text { Indoor Temperature }\left({ }^{\circ} \mathrm{C}\right) \\
\text { (Calculation Sheet-Setup } \\
\text { Temperature) }\end{array}$} & \multicolumn{2}{|c|}{ Average Temperature $\left({ }^{\circ} \mathrm{C}\right)$} \\
\hline & & & $\begin{array}{c}\text { Mechanical } \\
\text { Outlet }\end{array}$ & $\begin{array}{l}\text { Mechanical Outlet } \\
\text { + Natural Wind }\end{array}$ \\
\hline 1 & $\begin{array}{c}\text { Used cable } \\
\text { processing room }\end{array}$ & 40 & 37.2 & 37.1 \\
\hline 2 & 23 kV GIS room & 40 & 38.3 & 38.3 \\
\hline 3 & Generator room & 40 & 37.0 & 37.0 \\
\hline 4 & $\begin{array}{l}\text { Main transformer } \\
\text { room }\end{array}$ & 40 & 38.3 & 38.3 \\
\hline 5 & SC room & 40 & 37.0 & 37.0 \\
\hline 6 & $\begin{array}{l}\text { Fire equipment } \\
\text { room }\end{array}$ & 40 & 37.5 & 37.5 \\
\hline
\end{tabular}




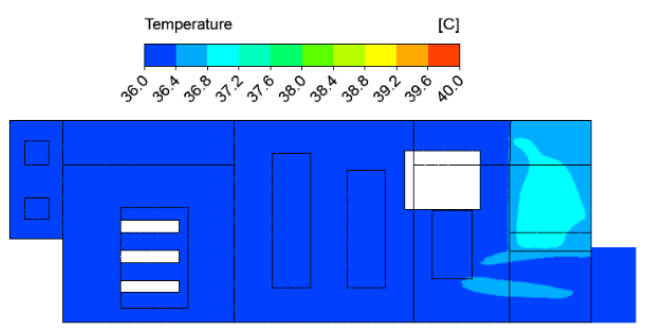

Mechanical outlet - basement at a height of $2.0 \mathrm{~m}$ from the floor - temperature gradation map

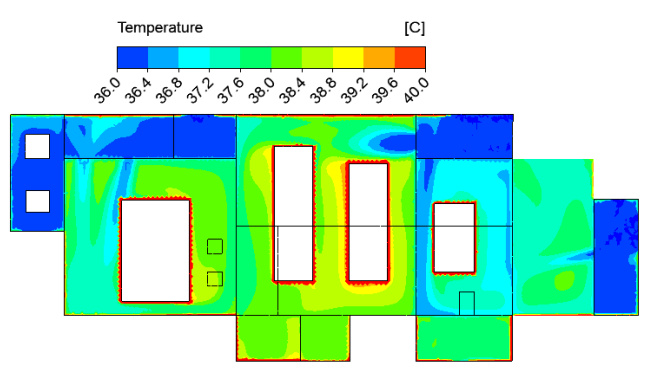

Mechanical outlet - Floor 1 at a height of $2.0 \mathrm{~m}$ from the floor - temperature gradation map

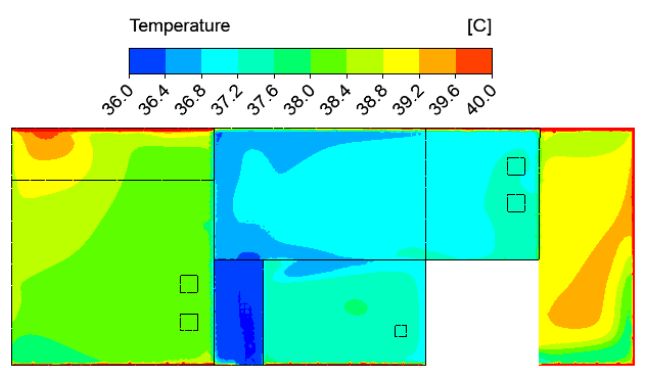

Mechanical outlet - Floor 2 at a height of $2.0 \mathrm{~m}$ from the floor - temperature gradation map

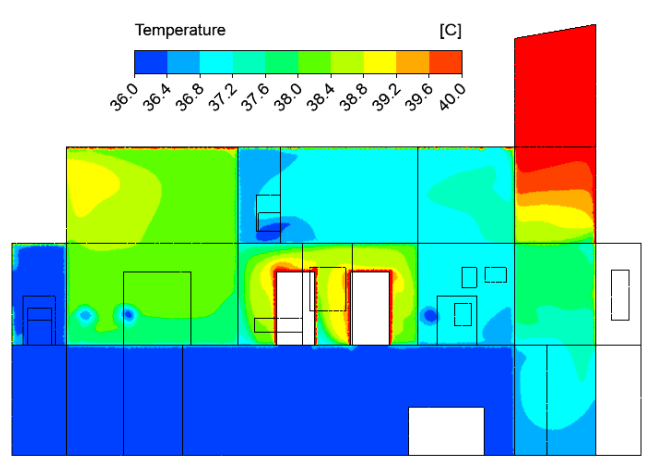

Mechanical outlet - building longitudinal section 1 temperature level map

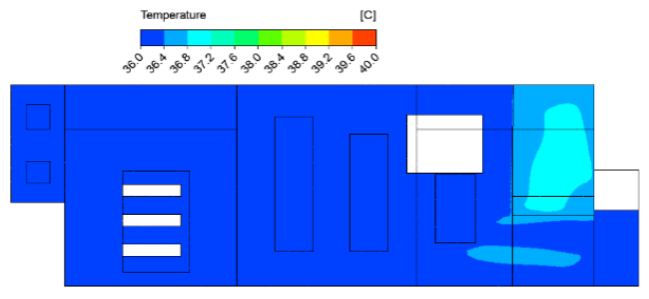

Mechanical outlet and outdoor natural wind in joint operations - basement at a height of $2.0 \mathrm{~m}$ from the floor temperature gradation map

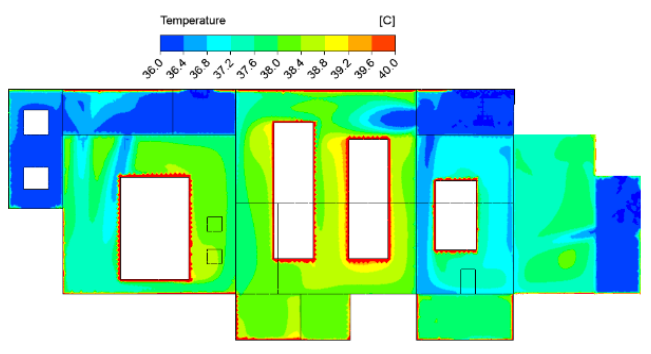

Mechanical outlet and outdoor natural wind in joint operations - Floor 1 at a height of $2.0 \mathrm{~m}$ from the floor temperature gradation map

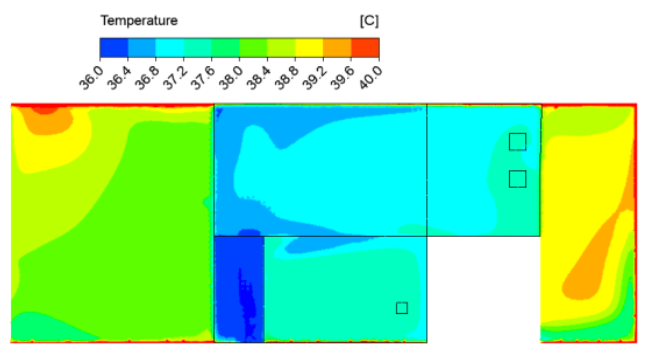

Mechanical outlet and outdoor natural wind in joint operations - Floor 2 at a height of $2.0 \mathrm{~m}$ from the floor temperature gradation map

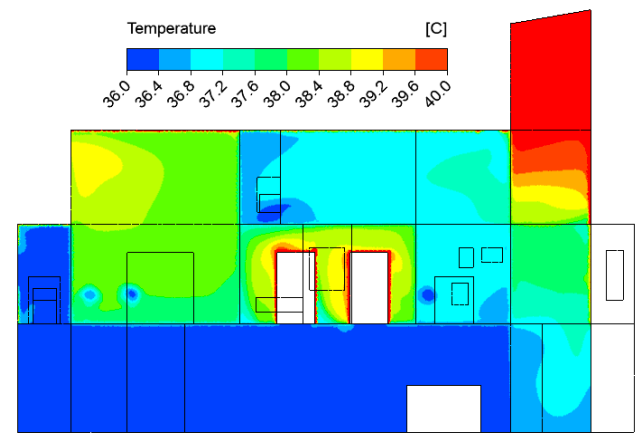

Mechanical outlet and outdoor natural wind in joint operations - building longitudinal section 1 - temperature gradation map

Figure 13. Cont. 


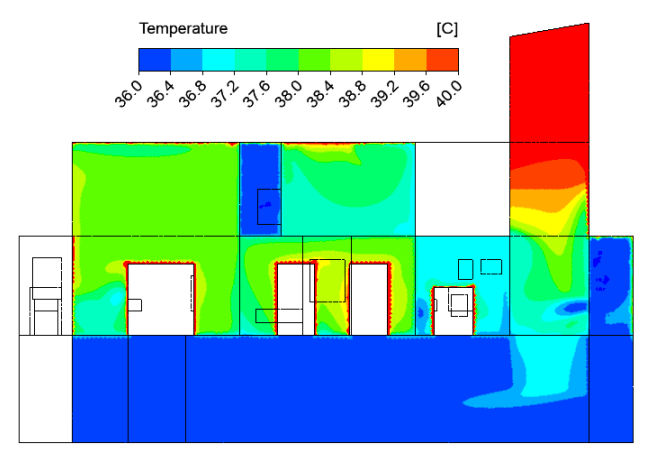

Mechanical outlet - building longitudinal section 2 temperature level map

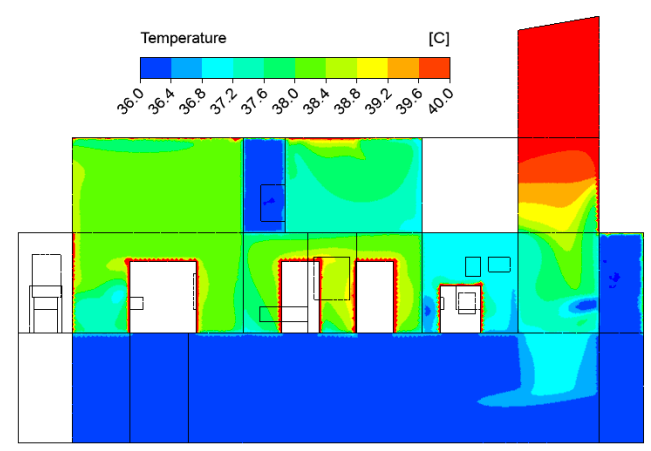

Mechanical outlet and outdoor natural wind in joint operations - building longitudinal section 2 - temperature gradation map

Figure 13. Indoor temperature distributions based on mechanical outlet or mechanical outlet + outdoor natural wind.

\section{Conclusions}

\subsection{The Study Results}

In this study, the MOPSO multi-target performance pointer was initially applied for optimizing the ventilation system of the equipment room in Taiwan's transformer substations on the premise that the air inlet of the equipment room is arranged on the windward side and within $1 \mathrm{~m}$ on the floor, the exhaust outlet (thermal convection) is arranged on the roof of the equipment room and the, inlet/outlet is fixed. The optimization of inlet/outlet size helps to reduce the indoor temperature, realize energy conservation of exhaust fans of cooling equipment, and reduce the synthetic noise of the transformer substation; moreover, CFD software, which has been used in the reported investigations on the ventilation system of transformer substations worldwide, was used for verifying the performance of the air inlet on the windward side of the building and indoor cooling, which is a pioneering work among reports on ventilation systems of transformer substations worldwide. This is the scientific contribution of this study.

While researchers such as Petri et al. [7] and Ma et al. [8] reduced the annual electricity bill based on intelligent equipment scheduling for HVAC equipment in buildings that have completed construction, this study has been incorporated into the intelligent green building energy design before the building was used. Moreover, because researchers have mixed gene particle group optimization, PSO, and gene optimization algorithms to compare convergence time and iteration times [45], the results can be processed quickly according to the current computer's CPU execution speed. Therefore, this study focuses on the reduction in the power of the ventilation system using the MOPSO algorithm for cost reduction while maintaining the system's performance. After the indoor and outdoor models of the building substation are built using BIM, the results are simulated via ANSYS FLUENT 18.0 to verify the overall performance.

We use formula (5) and evaluate the heat generation of the equipment listed in Tables 2 and 3 according to the equipment in the equipment room and the difference between indoor and outdoor temperatures to calculate the required ventilation volume $\mathrm{A}$ of the equipment room. We use formula (4) and the ventilation rate of the equipment room (Table 1) to calculate the ventilation volume $B$. Ventilation volumes A and B are selected to have the largest value for planning the horsepower of the mechanical exhaust fan in this equipment room; however, the combined noise value of all exhaust fans in this equipment room does not exceed $70 \mathrm{dBA}$ (the synthetic noise limit value). The exhaust fan for each equipment room must reduce the temperature of the exhaust gas, and the synthetic noise of the exhaust fan must be less than $70 \mathrm{dBA}$ to prevent the noise generated by its operation from disturbing the nearby residents. The next consideration is the power reduction of the ventilation 
system. The exhaust fan in each equipment room has a daily fixed 30-min operational period. In addition to ventilating and cooling the interior air of the equipment room, this restriction also prevents damage to the exhaust fan equipment if it is left unused for some time. Furthermore, the exhaust fan in the equipment room has a fixed temperature operation of $30 \mathrm{~min}$. For example, the indoor exhaust fan is set to operate at a fixed temperature of $40^{\circ} \mathrm{C}$; as the summer is hot and the equipment in the equipment room generates heat, the exhaust fan is often triggered to operate at a constant temperature. Thus, the hottest time of the day in summer is at noon. If the daily scheduled operation is set to noon, it can reduce the constant operational temperature of the equipment room from exceeding $40^{\circ} \mathrm{C}$ during the hottest period of the day without the need to trigger the constant temperature and timed operations. In one hour, the mechanical exhaust of the exhaust fan operates twice. It only needs to run for $30 \mathrm{~min}$ at a time, which can reduce electricity bills over the year.

As proposed title in this thesis for power substation construction and ventilation system co-design using particle swarm optimization, the best and most economical way is to use construction methods to naturally reduce the power of the exhaust fan. This can save electricity costs and reduce the combined fan noise to achieve the objectives of environmental protection, energy saving, and carbon saving.

\subsection{Discussion}

Because this study is used for ventilation planning prior to construction, it can, in the future, be applied to buildings that have been in operation for many years. The machine learning MOPSO algorithm is used to redesign the intake and exhaust ports and to focus construction around those ports. This approach will reduce electricity costs and the noise of ventilation systems even in buildings that have been operating for years. This study is relevant even to the current Coronavirus pandemic. In indoor places (e.g., hospitals and other public spaces), ventilation effects require more attention to reduce infection spread. A Coronavirus quarantine experiment box's access and vent equipment are used to avoid infecting nearby quarantine personnel. Thus, to optimize the air intake and exhaust of buildings or of quarantine equipment, the mechanical exhaust method is used to safely exhaust the indoor virus-containing air so as to prevent its accumulation indoors. To conduct research in the future, one can start with the space of a coronavirus quarantine experiment box and then expand it to the larger space of a hospital. However, currently, the amount of ventilation must be increased to minimize the number of viruses or bacteria in a given space. Larger ventilation will increase the exhaust horsepower. Therefore, it is necessary to consider the amount of ventilation, the number of bacteria in the space, and the horsepower of the exhaust fan; these three indicators determine the optimal ventilation inlet and outlet opening size.

Author Contributions: J.-W.P. and Y.-C.K. have made substantial contributions to the conception and design of the work, along with the acquisition, analysis, and interpretation of data for the work. Y.-C.K. has contributed in drafting the work and critically revising it for important intellectual content. Y.-T.C. and H.-H.C. facilitated the final approval of the version to be published. All authors have read and agreed to the published version of the manuscript.

Funding: This study was funded by a grant from Ministry of Science and Technology, Taiwan, under Grant no. MOST 108-2638-E-009-001-MY2.

Acknowledgments: The authors appreciate the contributions provided from Chih-Tang Li and Te-Chung Huang of Taiwan Power Company Southern Region Construction Office and Steve Haga of Department of Computer Science and Engineering, National Sun Yat-sen University.

Conflicts of Interest: The authors declare no conflict of interest.

\section{References}

1. Wang, L.; Greenberg, S. Window operation and impacts on building energy consumption. Energy Build. 2015, 1, 313-321. [CrossRef]

2. Lomas, K.J.; Ji, Y. Resilience of naturally ventilated buildings to climate change: Advanced natural ventilation and hospital wards. Energy Build. 2009, 41, 629-653. [CrossRef] 
3. Lomas, K.J.; Cook, M.J.; Fiala, D. Low energy architecture for a severe US climate: Design and evaluation of a hybrid ventilation strategy. Energy Build. 2007, 39, 32-44. [CrossRef]

4. Omer, A.M. Renewable building energy systems and passive human comfort solutions. Renew. Sustain. Energ. Rev. 2008, 12, 1562-1587. [CrossRef]

5. Yu, T.; Heiselberg, P.; Lei, B.; Pomianowski, M.; Zhang, C. A novel system solution for cooling and ventilation in office buildings: A review of applied technologies and a case study. Energy Build. 2015, 90, 142-155. [CrossRef]

6. Charvat, P.; Jicha, M.; Niachou, A.; Santamouris, M. Simulation of the performance of a hybrid ventilation system in different climates. In Proceedings of the Ninth International IBPSA Conference, Ecole Polytechnique de Montréal, Montreal, QC, Canada, 15-18 August 2005.

7. Petri, I.; Kubicki, S.; Rezgui, Y.; Guerriero, A.; Li, H. Optimizing energy efficiency in operating built environment assets through building information modeling: A case study. Energies 2017, 10, 1167. [CrossRef]

8. Ma, K.; Yu, Y.; Yang, B.; Yang, J. Demand-side energy management considering price oscillations for residential building heating and ventilation systems. IEEE Trans. Ind. Inform. 2019, 15, 4742-4752. [CrossRef]

9. Sporr, A.; Zucker, G.; Hofmann, R. Automated HVAC control creation based on building information modeling (BIM): Ventilation system. IEEE Access 2019, 7, 74747-74758. [CrossRef]

10. Ke, M.T.; Cheng, T.C.; Wang, W.P. Numerical simulation for optimizing the design of subway environmental control system. Build. Environ. 2002, 37, 1139-1152. [CrossRef]

11. Liu, H.; Hao, Y.P.; Fu, M.L.; Wang, D.B.; Yang, L. Study on ventilation of indoor substation main transformer room based on COMSOL software. In Proceedings of the 2017 1st International Conference on Electrical Materials and Power Equipment (ICEMPE), Xi'an, China, 14-17 May 2017; pp. 296-300. [CrossRef]

12. Kanaan, M.; Chahine, K. CFD study of ventilation for indoor multi-zone transformer substation. Int. J. Heat Technol. 2018, 36, 88-94. [CrossRef]

13. Bahri, F.A.S.; Hasini, H. Flow and heat dissipation analysis in transformer substation with minimal ventilation using CFD. Int. J. Eng. Technol. (UAE) 2018, 7, 327-332. [CrossRef]

14. Liu, Y.; Ye, W.; Li, Y.; Chen, T.; Hu, K. Ventilation Optimization for Reduction of Indoor Air Temperature of Main Transformer Room in Urban Indoor Substation by the Variational Method. J. Therm. Sci. 2019, 28, 1089-1101. [CrossRef]

15. Liu, F.; Tu, S.; Yan, H.; Chen, X.; Guo, L. Analysis of Noise Environment and Noise Reduction Measures in Urban 110kV Indoor Substations. E3S Web Conf. 2020, 145, 02066. [CrossRef]

16. Kar, P.; Chattopadhyay, S.; Ivanov, O.; Gavrilas, M. Optimal Demand Response Allocation in Distribution Networks Using the PSO Algorithm. In Proceedings of the 2018 International Conference and Exposition on Electrical and Power Engineering (EPE), Iasi, Romania, 18-19 October 2018. [CrossRef]

17. Gampa, S.R.; Jasthi, K.; Goli, P.; Das, D.; Bansal, R.C. Grasshopper Optimization Algorithm Based Two Stage Fuzzy Multiobjective Approach for Optimum Sizing and Placement of Distributed Generations, Shunt Capacitors and Electric Vehicle Charging Stations. J. Energy Storage 2020, 27. [CrossRef]

18. Pan, Z.; Chen, M.; Lu, S.; Tian, Z.; Liu, Y. Integrated Timetable Optimization for Minimum Total Electrical Energy Consumption of an AC Railway System. IEEE Trans. Veh. Technol. 2020. [CrossRef]

19. Adedeji, P.A.; Akinlabi, S.; Madushele, N.; Olatunji, O.O. Wind Turbine Power Output Short-Term Forecast: A Comparative Study of Data Clustering Techniques in a PSO-ANFIS Model. J. Clean. Prod. 2020, 254. [CrossRef]

20. Naidu, K.; Ali, M.S.; Abu Bakar, A.H.; Tan, C.K.; Arof, H.; Mokhlis, H. Optimized Artificial Neural Network to Improve the Accuracy of Estimated Fault Impedances and Distances for Underground Distribution System. PLoS ONE 2020, 15, e0227494. [CrossRef]

21. Jain, V.K. Fire Safety in Building, 2nd ed.; New Age International Private Limited Publishers: Maharashtra, India, 2010.

22. Building Act. Rev. 2020. Available online: https://www.cpami.gov.tw/public-information/laws-regulations/ 9-building-and-construction/10789-building-act $\% \mathrm{EF} \% \mathrm{BC} \% 88 \% \mathrm{E} 5 \% \mathrm{BB} \% \mathrm{BA} \% \mathrm{E} 7 \% \mathrm{AF} \% 89 \% \mathrm{E} 6 \% \mathrm{B3} \% 95 \%$ EF\%BC\%89.html (accessed on 28 March 2020).

23. Building Technical Regulations (Construction Section). Rev. 2019. Available online: https://law.moj.gov.tw/ LawClass/LawAll.aspx?pcode=D0070115 (accessed on 28 March 2020).

24. Sarfraz, O.; Bach, C.K. Equipment power consumption and load factor profiles for buildings' energy simulation (ASHRAE 1742-RP). Sci. Technol. Built Environ. 2018, 24, 1054-1063. [CrossRef] 
25. Cutnell, J.D.; Johnson, K.W. Physics, 4th ed.; John Wiley \& Sons Inc.: Hoboken, NJ, USA, 1997.

26. Moody, L.F. Friction factors for pipe flow. Trans. ASME 1944, 66, 671-684.

27. Churchill, S.W. Friction factor equation spans all fluid flow regimes. Adv. Eng. Res. 1977, 84, 91-92.

28. Guffey, S.E. Friction tables determined from colebrook's equation for standard density air flow. Appl. Occup. Environ. Hyg. 1992, 7, 453-466. [CrossRef]

29. Huebscher, R.G. Friction equivalents for round, square, and rectangular ducts. ASHRAE Trans. 1948, 54, 101-144.

30. McDermott, H.J. Handbook of Ventilation for Contaminant Control, 2nd ed.; Butterworth: Waltham, MA, USA, 1985.

31. ACGIH. Industrial Ventilation, a Manual of Recommended Practice, 21st ed.; American Conference of Governmental Industrial Hygienists: Cincinnati, OH, USA, 1992.

32. Burgess, W.A.; Ellenbecker, M.J.; Treitman, R.D. Ventilation for Control of the Work Environment; John Wiley \& Sons Inc.: Hoboken, NJ, USA, 1982.

33. ASHRAE. ANSI/ASHRAE STANDARD 62-2001-Ventilation for Acceptable Indoor Air Quality; American Society of Heating, Refrigerating and Air Conditioning Engineers: Atlanta, GA, USA, 2001.

34. Kennedy, J.; Eberhart, R. Particle swarm optimization. In Proceedings of the Fourth IEEE International Conference on Neural Networks, Perth, WA, Australia, 27 November-1 December 1995; Volume 4, pp. 1942-1948. [CrossRef]

35. Shi, Y.; Eberhart, R.C. A modified particle swarm optimizer. In Proceedings of the IEEE International Conference on Evolutionary Computation (ICEC), Anchorage, AK, USA, 4-9 May 1998; pp. 69-72. [CrossRef]

36. Hu, X.; Shi, Y.; Eberhart, R.C. Recent advances in particle swarm. In Proceedings of the IEEE Congress on Evolutionary Computation, Portland, OR, USA, 19-23 June 2004; pp. 90-97. [CrossRef]

37. Perng, J.W.; Kuo, Y.C.; Lu, S.P. Grounding system cost analysis using optimization algorithms. Energies 2018, 11, 3484. [CrossRef]

38. Perng, J.; Kuo, Y.; Lu, K. Design of the PID Controller for Hydro-turbines Based on Optimization Algorithms. Int. J. Control Autom. Syst. 2020, 1-3. [CrossRef]

39. Liguori, C.; Ruggiero, A.; Russo, D.; Sommella, P. Innovative bootstrap approach for the estimation of minimum measurement time interval in road traffic noise evaluation. Measurement 2017, 98, 237-242. [CrossRef]

40. Gao, X.; Pishdad-Bozorgi, P. BIM-enabled facilities operation and maintenance: A review. Adv. Eng. Inform. 2019, 39, 227-247. [CrossRef]

41. Gerrish, T.; Ruikar, K.; Cook, M.; Johnson, M.; Phillip, M.; Lowry, C. BIM application to building energy performance visualisation and management: Challenges and potential. Energy Build. 2017, 144, 218-228. [CrossRef]

42. Ibrahim, M.; Kate, C. Sustainable BIM-based evaluation of buildings. Int. Proj. Manag. Assoc. 2013, 74, 419-428. [CrossRef]

43. Król, A.; Król, M. Study on hot gases flow in case of fire in a road tunnel. Energies 2018, 11, 590. [CrossRef]

44. Król, A.; Król, M. Transient analyzes and energy balance of air flow in road tunnels. Energies 2018, 11, 1759. [CrossRef]

45. Alik, B.; Teguar, M.; Mekhaldi, A. Minimization of grounding system cost using PSO, GAO, and HPSGAO techniques. IEEE Trans. Power Deliv. 2015, 30, 2561-2569. [CrossRef]

(C) 2020 by the authors. Licensee MDPI, Basel, Switzerland. This article is an open access article distributed under the terms and conditions of the Creative Commons Attribution (CC BY) license (http://creativecommons.org/licenses/by/4.0/). 